\title{
Light Water Reactor Sustainability (LWRS) Program - Non-Destructive Evaluation (NDE) R\&D Roadmap for Determining Remaining Useful Life of Aging Cables in Nuclear Power Plants
}
KL Simmons
HM Hashemian
P Ramuhalli
R Konnick
DL Brenchley
JB Coble
S Ray

September 2012

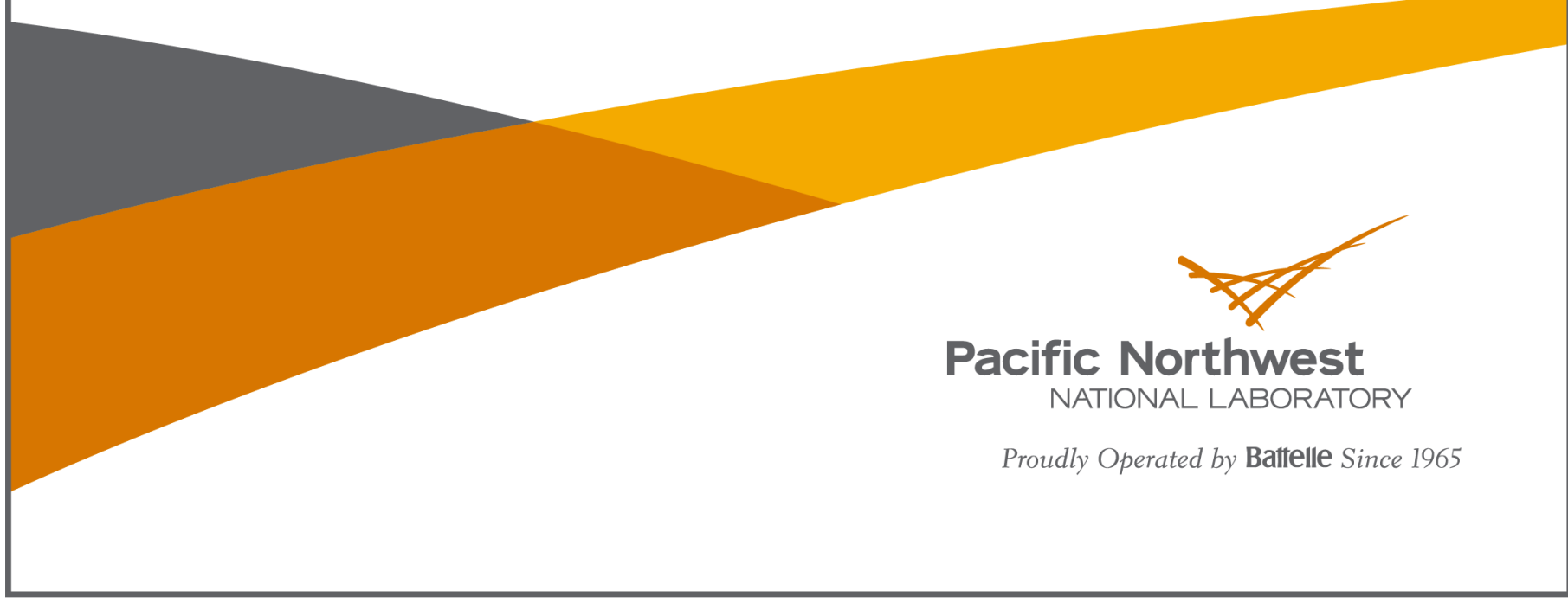




\title{
DISCLAIMER
}

This report was prepared as an account of work sponsored by an agency of the United States Government. Neither the United States Government nor any agency thereof, nor Battelle Memorial Institute, nor any of their employees, makes any warranty, express or implied, or assumes any legal liability or responsibility for the accuracy, completeness, or usefulness of any information, apparatus, product, or process disclosed, or represents that its use would not infringe privately owned rights. Reference herein to any specific commercial product, process, or service by trade name, trademark, manufacturer, or otherwise does not necessarily constitute or imply its endorsement, recommendation, or favoring by the United States Government or any agency thereof, or Battelle Memorial Institute. The views and opinions of authors expressed herein do not necessarily state or reflect those of the United States Government or any agency thereof.

\author{
PACIFIC NORTHWEST NATIONAL LABORATORY \\ operated by \\ BATTELLE \\ for the \\ UNITED STATES DEPARTMENT OF ENERGY \\ under Contract DE-AC05-76RL01830
}

Printed in the United States of America
Available to DOE and DOE contractors from the Office of Scientific and Technical Information,
P.O. Box 62, Oak Ridge, TN 37831-0062;
ph: (865) 576-8401
fax: (865) 576-5728
email: reports@adonis.osti.gov

\author{
Available to the public from the National Technical Information Service, \\ U.S. Department of Commerce, 5285 Port Royal Rd., Springfield, VA 22161 \\ ph: (800) 553-6847 \\ fax: (703) 605-6900 \\ email: orders@ntis.fedworld.gov \\ online ordering: http://www.ntis.gov/ordering.htm
}

This document was printed on recycled paper.

$(9 / 2003)$ 


\title{
Light Water Reactor Sustainability (LWRS) Program - Non-Destructive Evaluation (NDE) R\&D Roadmap for Determining Remaining Useful Life of Aging Cables in Nuclear Power Plants
}

\author{
KL Simmons \\ HM Hashemian ${ }^{1}$ \\ P Ramuhalli \\ R Konnick ${ }^{2}$ \\ DL Brenchley \\ JB Coble \\ S Ray ${ }^{3}$
}

September 2012

Prepared for

the U.S. Department of Energy

under Contract DE-AC05-76RL01830

Pacific Northwest National Laboratory

Richland, Washington 99352

\footnotetext{
${ }^{1}$ AMS Corporation

${ }^{2}$ Rockbestos Cable Corporation

${ }^{3}$ U.S. Nuclear Regulatory Commission
} 
PNNL-21731 


\section{Executive Summary}

The purpose of the non-destructive evaluation (NDE) R\&D Roadmap for Cables is to support the Materials Aging and Degradation (MAaD) R\&D pathway. A workshop was held to gather subject matter experts to develop the NDE R\&D Roadmap for Cables. The focus of the workshop was to identify the technical gaps in detecting aging cables and predicting their remaining life expectancy. The workshop was held in Knoxville, Tennessee, on July 30, 2012, at Analysis and Measurement Services Corporation (AMS) headquarters. The workshop was attended by 30 experts in materials, electrical engineering, and NDE instrumentation development from the U.S. Nuclear Regulatory Commission (NRC), U.S. Department of Energy (DOE) National Laboratories (Oak Ridge National Laboratory, Pacific Northwest National Laboratory, Argonne National Laboratory, and Idaho National Engineering Laboratory), universities, commercial NDE service vendors and cable manufacturers, and the Electric Power Research Institute (EPRI).

The motivation for the R\&D roadmap comes from the need to address the aging management of incontainment cables at nuclear power plants (NPPs). The most important criteria for cable performance is its ability to withstand a design basis accident. With nearly $1000 \mathrm{~km}$ of power, control, instrumentation, and other cables typically found in an NPP, it would be a significant undertaking to inspect all of the cables. Degradation of the cable jacket, electrical insulation, and other cable components is a key issue that is likely to affect the ability of the currently-installed cables to operate safely and reliably for another 20 to 40 years beyond the initial operating life. The development of one or more NDE techniques and models that could assist in determining the remaining life expectancy of cables or their current degradation state would be of significant interest. The ability to non-destructively determine material and electrical properties of cable jackets and insulation without disturbing the cables or connections is essential.

The major emphasis of the workshop focused on the chemical changes in the material caused by the environment (thermal, radiation, and moisture, its relationship to mechanical, physical, and electrical property changes of dielectric materials used in cable insulation and jackets and the current state-of-theart in NDE techniques for detecting aging and degradation of cables. The only current technique accepted by industry to measure cable elasticity (the gold standard for determining cable insulation degradation) is the indentation measurement. All other NDE techniques are used to find flaws in the cable and do not provide information to determine the current health or life expectancy.

Currently, there is no single NDE technique that can satisfy all of the requirements needed for making a life expectancy determination, but a wide range of methods have been evaluated for use in NPPs as a part of a continuous evaluation program. The commonly used methods are indentation and visual inspection, but these are only suitable for easily accessible cables. Several NDE methodologies utilizing electrical techniques are in use today for flaw detection but there are none that can predict the life of a cable.

The results from the workshop identified three key areas of importance:

1. Determine key indicators of cable aging that correlate with measureable changes in material properties at the macroscopic scale. 
2. Advance state-of-the-art in current cable NDE methods and develop new and transformational NDE methods to enable in-situ cable condition measurements that can be used to assess remaining life expectancy. The data for these developments would be collected from samples generated in laboratory cable aging experiments as well as field samples.

3. Develop models for predicting remaining useful life of cables based on condition indices. The data for these models would come from existing databases, the information generated in topic 1 and 2 , and other relevant sources.

In order to make a determination on the appropriate NDE technology or the need for a new technology, the key indicators of cable aging need to be identified so correlations with measureable changes in material properties at the macroscopic scale can be evaluated with the right sensitivity and measurement technique. Depending on the insulating material type, the environmental effects can happen at different degradation rates and mechanisms that change the properties. For example, ethylenepropylene rubber (EPR) can undergo thermal or radiation degradation at different rates depending on temperature or radiation dose rate. However, cross-linked polyethylene has been shown in laboratory experiments to experience an inverse temperature effect that ages the cable faster at lower temperatures with radiation.

With the determination of key indicators, advancing current state-of-the-art cable NDE methods or developing new NDE methods can close the gap with measuring material properties. Non-invasive methods are needed that are capable of measuring in discrete and difficult to access locations. In order to evaluate any new or advanced NDE method, laboratory and field aged material samples for experimentation are required to evaluate the sensitivity for identifying the key indicators to aging and to compare candidate NDE techniques.

With data from advanced NDE methods or new technologies to measure indicators of cable aging, prognostic models are needed for predicting remaining useful life of cables based on their condition and future operating environments. The NDE measurements and corresponding models will provide important information to the Light Water Reactor Sustainability (LWRS) program about the current and future condition of cables in NPPs. The data for these models would come from existing databases and information generated in improving, developing, and evaluating NDE techniques.

A consistent theme from the LWRS NDE workshops was the need for a comprehensive and fully characterized common set of samples for NDE experimentation. The required cable samples would need to be representative of various cable materials, configurations, and environmental conditions that could be characterized by destructive techniques for baseline properties and established as calibration references for NDE techniques. In order to achieve the DOE vision for NDE research on cable aging management, this sample set must be assembled.

The workshop concluded that some emerging NDE techniques show promise for detecting cable flaws and some existing instrumentation may be suitable, but new algorithms and techniques need to be developed for alternative property measurements and characterizing changes in cable aging. Promising emerging techniques include non-linear ultrasonic, Fourier infrared spectroscopy, frequency or timedomain reflectometry, and dielectric based techniques. These techniques may offer a method of nondestructive characterization of cables which can then be correlated to the remaining cable life. 


\section{Acronyms}

$\begin{array}{ll}\text { AMP } & \text { aging management program } \\ \text { AMS } & \text { Analysis and Measurement Services Corporation } \\ \text { CRP } & \text { coordinated research project } \\ \text { DOE } & \text { U.S. Department of Energy } \\ \text { EAB } & \text { elongation of break } \\ \text { EPR } & \text { ethylenepropylene rubber } \\ \text { EPRI } & \text { Electric Power Research Institute } \\ \text { GALL } & \text { Generic Aging Lessons Learned } \\ \text { IAEA } & \text { International Atomic Energy Agency } \\ \text { IR } & \text { infrared } \\ \text { ISI } & \text { in-service inspection } \\ \text { LTO } & \text { long-term operation } \\ \text { LWRS } & \text { Light Water Reactor Sustainability Program } \\ \text { MAaD } & \text { Materials Aging and Degradation } \\ \text { NDE } & \text { nondestructive evaluation } \\ \text { NPP } & \text { nuclear power plant } \\ \text { NRC } & \text { U.S. Nuclear Regulatory Commission } \\ \text { SSC } & \text { systems, structures, and components }\end{array}$





\section{Contents}

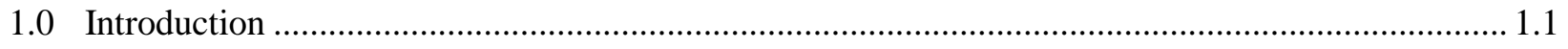

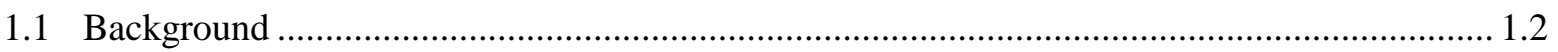

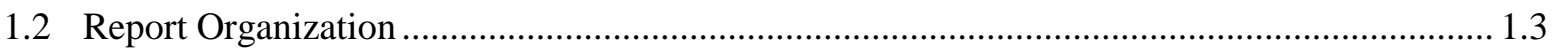

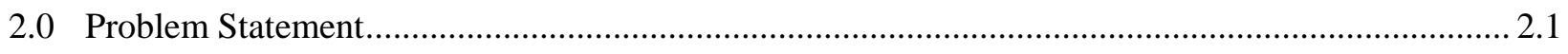

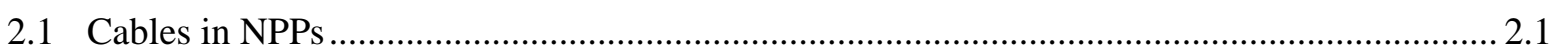

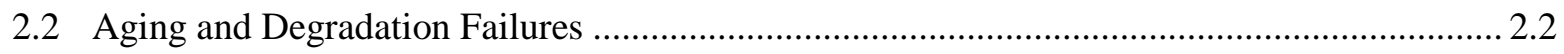

3.0 NDE for Cable Aging and Degradation Detection: Current State of the Art ................................ 3.1

4.0 NDE Research \& Development Roadmap for Evaluation of Aging Cables and Degradation in NPP for Determining Remaining Useful Life ....................................................................... 4.1

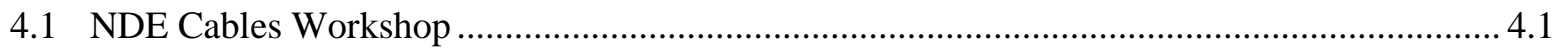

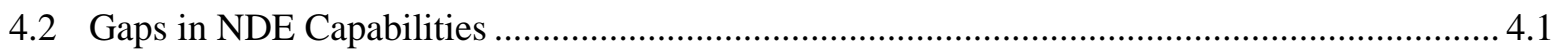

4.3 Need for Determining Key Aging Indicators .................................................................... 4.5

4.4 Need for Developing Models for Predicting Remaining Useful Life of Cables Based on

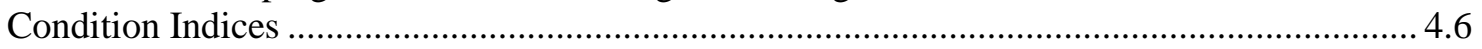

4.5 Need to Survey Availability of Aged Cables for NDE Samples .......................................... 4.6

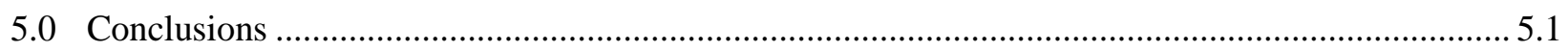

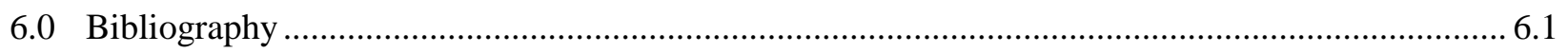

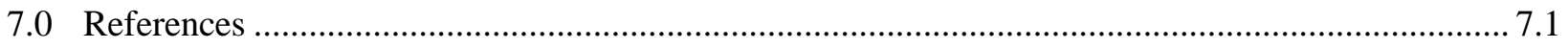

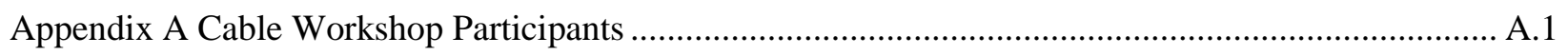

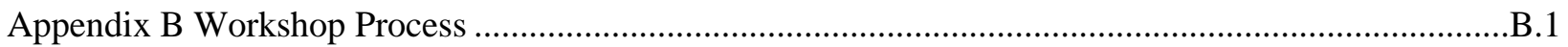




\section{Figures}

Figure 4.1. Usefulness of NDE in Predicting Remaining Cable Life .................................................. 4.2

Figure 4.2. Proposal Ranking by the Working Group ........................................................................ 4.4

Figure 4.3. Illustration of Flow of Research for NDE Development and RUL Models ......................... 4.5

\section{Tables}

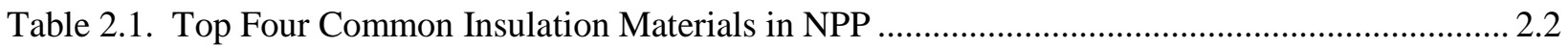

Table 3.1. Most Common Methods Currently Considered Viable for Cable Inspection.......................... 3.2

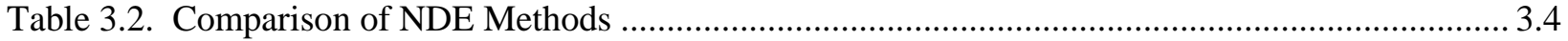

Table 4.1. A Summary of the Main Gaps Identified.............................................................................. 4.2 


\subsection{Introduction}

The Department of Energy's (DOE) Light Water Reactor Sustainability (LWRS) Program is developing the fundamental scientific basis to understand, predict, and measure changes in materials and systems, structures, and components (SSCs) as they age in environments associated with continued longterm operations (LTO) of existing commercial nuclear power plants (NPPs). Research under the LWRS Program is being conducted within four pathways:

1. Materials Aging and Degradation

2. Advanced Instrumentation, Information and Control Systems

3. Risk-Informed Safety Margins Characterization

4. Advanced Light Water Reactor Nuclear Fuels

A key element of LTO of LWRs is expected to be the management of aging and degradation in materials that make up the passive safety system components. Understanding the likely degradation mechanisms in these materials under LTO is essential. At the same time, approaches to assess the condition of these materials in a nondestructive fashion will also be necessary to assure adequate safety margins and ensure that an effective aging management program can be set up for LTO. The objective of the LWRS Materials Aging and Degradation (MAaD) R\&D pathway is to create a greater level of safety through application of increased knowledge and an enhanced economic understanding of plant operational risk beyond the first license extension period. R\&D is being conducted to develop the scientific basis for understanding and predicting long-term environmental degradation behavior of materials in NPPs. Data and methods to assess the performance of SSCs essential to safe and sustained NPP operations are being developed. These R\&D products will be used to define operational limits and aging mitigation approaches for materials in NPP SSCs that are subject to long-term operating conditions.

License extensions for extended-LTO (i.e., 60-80 years, and beyond) will require a shift to a more proactive approach to aging management in addition to updated approaches to periodic in-service inspection (ISI). Three overarching elements of research are necessary to develop a proactive aging management philosophy and these include:

- Integration of materials science understanding of degradation accumulation, with nondestructive measurement science for early detection of materials degradation.

- Development of robust sensors and instrumentation, as well as deployment tools, to enable extensive condition assessment of passive NPP components.

- Analysis systems for condition assessment and remaining life estimation from measurement data.

It is likely that tackling these research elements in parallel will be necessary to address anticipated near-term deadlines for life extension decision-making ( $1{ }^{\text {st }}$ of the second round license extension packets may be received by the NRC 2014/15, with decision needed by 2019 or 2020).

To address the research needs, the MAaD Pathway of the LWRS program supported a series of workshops in the summer of 2012 with the objective of identifying technical gaps and prioritizing research in nondestructive evaluation (NDE) methods. This document summarizes the findings of the workshop addressing NDE R\&D for Detection of Cable Aging and Degradation. 


\subsection{Background}

The motivation for this $R \& D$ roadmap for cable evaluation comes from the need to address the aging management of in-containment cables at NPPs. With nearly $1000 \mathrm{~km}$ of power, control, instrumentation and other cables typically found in an NPP, it would be a significant undertaking to inspect all of the cables through the currently employed cable inspection techniques, such as visual inspection or the indenter modulus. Degradation of the cable jacket, electrical insulation, and other cable components are key issues for assessing the ability of the currently-installed cables to operate safely and reliably for another 20 to 40 years beyond the initial operating life. The development of one or more NDE techniques and models that could assist in determining the current condition or remaining life expectancy of cables would be of significant interest. The ability to non-destructively determine material and electrical properties without disturbing the cables or connections is essential.

The U.S. fleet of commercial nuclear power reactors has an average age of more than 30 years, and most of the fleet has either applied for or received an extension of the operating license from 40 years to 60 years (NRC 2011). Attention is now turning to the potential for a second round of license extensions (Chockie et al. 1991; Bond 1999; Gregor and Chockie 2006; Bond et al. 2008). A challenge to safe, longterm operations is the life-limiting nature of materials aging and degradation, as such aging and associated degradation in the structural response of the material can limit safety margins. Replacement of a subset of components (such as the steam generator) may be possible, though the costs associated with the replacement (including the time offline) may be challenging. Moreover, it is economically prohibitive to replace several of the larger components, including the expanse of cables employed in an NPP. Thus, management and mitigation of aging-related degradation in critical components becomes important to maintaining safety margins.

Components of concern include cables, including power, control, and instrumentation cables. In the context of long term operations, aging of the outer jacket and electrical insulation (both made of polymeric materials) are typically considered most significant (IAEA 2000). Degradation of these cables has largely been ignored because they are considered to be passive, long-lived components with high historical reliability. However, longer service life entails increased exposure to environmental stressors, such as temperature, irradiation, moisture, and humidity. Studies have demonstrated the detrimental effects of polymeric degradation on cable performance, and the number of cable failures has been shown to increase with plant age, even within the rated 40-year lifetime (Villaran and Lofaro 2010).

From a regulatory perspective, commercial NPPs are required to demonstrate adequate safety margins through multiple, independent, and redundant layers of protection (Diaz 2004). Regulatory guidance towards the management and mitigation of the effects of passive SSC aging in this regard is contained in the Generic Aging Lessons Learned (GALL) reports (NRC 2001, 2005a, b, 2010b). These reports provide the technical basis for determining whether plant aging management programs (AMPs) at operating reactors are adequate or need modification as plants enter extended operation. The AMP applies to all SSCs that are safety-related or whose failure could affect safety-related functions, as well as those SSCs relied on for compliance with fire protection, environmental qualification, pressurized thermal shock, anticipated transients without scram, or station blackout regulations. Specific programs that need modification are also identified, and the information in these reports is also included in the NRC's Standard Review Plan for Review of License Renewal Applications (NRC 2010a). 
One component of the AMP is the scheduled ISI of passive components, codified in 10 CRF 50.55a (2007), which specifies the requirements for reliable nondestructive inspection (such as inspection periodicity, inspection techniques, and qualification procedures). While the ISI program for metallic components (particularly Class 1 components) has been in existence for a number of years, a similar program for ISI of cables is lacking. This report is the outcome of a workshop on cable aging that examined the measurement and inspection needs and the current state of the art with respect to cable NDE, with the objectives to identify technical challenges in the application of NDE methods for cable aging detection and characterization and to define a research roadmap to address these challenges. The objective of the proposed research is the development of the scientific basis for reliably detecting and characterizing cable aging and degradation, to serve as input to licensing decisions for LTO.

\subsection{Report Organization}

The document is organized as follows. Section 2 discusses the measurement needs from a materials science perspective. Specifically, the impact of degradation mechanisms of concern on materials microstructure, and the key measurements that are needed for assessment of impact on structural integrity are summarized. Section 3 summarizes the state of the art in nondestructive measurements that may be applicable to the problem at hand. Section 4 discusses the gaps (as identified at the workshop) in NDE measurements for LTO and a research roadmap to address high priority gaps. Finally, Section 5 concludes the report and identifies a timeline for follow-on R\&D. In addition, appendices are included that provide details of the workshop process, outcomes of the workshop, and list of the attendees. 


\subsection{Problem Statement}

It is essential to define the materials aging and degradation problems including the mechanisms at play in cable aging. Specifically, what are the kinds of NDE measurements materials experts want to assess materials aging and degradation?

\subsection{Cables in NPPs}

The motivation for the R\&D roadmap comes from a 1993 International Atomic Energy Agency (IAEA)-initiated coordinated research project (CRP) to address the aging management of in-containment cables at NPPs. Because it simply is not practical to inspect the over $1000 \mathrm{~km}$ of cable typically found within an NPP, a prioritization scheme is necessary to limit cable inspection programs to a manageable level. In the context of aging management, the outer jacket and electrical insulation (both commonly made of polymeric materials, either the same material or combinations of different materials) are typically considered most significant. Typical cable architecture consists of one or several conductors individually wrapped with electrical insulation and bundled inside of a protective jacket. Three types of cables are of concern in nuclear power plants: (i) power, (ii) control, and (iii) instrumentation cables. Degradation of cables has largely been ignored because they are considered to be passive, long-lived components with high historical reliability. However, longer service life entails increased material exposure to environmental stressors, such as temperature, irradiation, moisture and humidity, local oxygen concentration, vibration, immersion in water through flooding of underground cable ducts, etc. Licensee data has shown that the number of cable failures is already increasing with plant age, even within the rated 40-year lifetime; extended operation will likely exacerbate the failure conditions. Degradation of the cable jacket, electrical insulation, and other cable components are key issues for assessing the ability of the currently installed cables to operate safely and reliably for 20 or 40 years beyond the initial operating life.

Cables present an interesting challenge because of the variety of environments experienced over the original 40 years of reactor life. Long cable runs used in some plant circuits may pass through several different environments over their length within the plant.

There are hundreds of types of cables in NPPs. These cables can be categorized as medium/low voltage cable, low voltage power cable, instrument and control cable, panel connect line cable, special cable, security line cable, phone line cable, light line cable and ground cable. According to the Sandia National Labs (2005), the distribution of circuits in an NPP are comprised of about $20 \%$ instrument cables, $61 \%$ control cables, $13 \%$ AC power cables, $1 \%$ DC power cables, and 5\% communication lines. Insulation and jacket materials in electrical cables are constructed based on polymer materials combined with a number of additives and fillers to provide the required mechanical, electrical, and fire retardant properties. The most commonly used insulation materials are XLPE, EPR/EPDM, Neoprene, and PVC. Table 2.1 shows that XLPE and EPR are $72 \%$ of the total entries. The top four materials (XLPE, EPR, silicone rubber, and Kerite) comprise over $80 \%$ of the total. Other materials may be used in the electrical systems but are at lower overall quantities; however, their performance is also of importance.

Table 2.1. Top Four Common Insulation Materials in NPP 


\begin{tabular}{llcc}
\hline Rank & Insulation Material & Entries & $\begin{array}{c}\text { Percentage } \\
\text { of Total }\end{array}$ \\
\hline 1 & XLPE & 439 & 36 \\
2 & EPR & 434 & 36 \\
3 & Silicone rubber & 63 & 5 \\
4 & Kerite & 61 & 5 \\
\hline
\end{tabular}

\subsection{Aging and Degradation Failures}

The main aging mechanisms of cable materials can be distinguished as chemical and physical. The aging mechanisms of cables are reported in the literature. Chemical aging mechanisms affect the molecular structure, while physical aging mechanisms affect the composition of the compound. Chemical aging mechanism from ionizing radiation, moisture, atmospheric gas, or thermal energy include scission of macromolecular chains, cross-linking reaction, oxidation diffusion, synergistic effect, and elimination of hydrochloric acid, while examples of physical aging mechanisms are evaporation and migration of plasticizer. The most common characterization methods of mechanical aging are elongation at break, tensile strength, and compressive modulus. Insulation resistance, dielectric strength, and dielectric loss are used to characterize electrical changes.

The aging of cable insulation or jacket material is important because aged cables can become hard and dry and crack, which can allow moisture intrusion into the cable resulting in corrosion, short circuits, shunting, and failure. While the loss of mechanical properties can have significant impact on the cable's physical integrity, the dielectric properties are also altered but are often still effective while the physical integrity is limited. In addition to the adverse effect on the plant operation and safety, such degradation or failure of cable insulation materials can be a fire hazard. 


\subsection{NDE for Cable Aging and Degradation Detection: Current State of the Art}

The most important criteria for cable performance in NPPs is the ability to withstand a design basis event. Cable integrity and function can be measured and monitored indirectly through in-service tests of safety-related systems and components. However, adequate function of the circuits under test conditions does not indicate the same satisfactory performance will occur during high stress events, such as operation when fully loaded or during extended periods as under normal service operation or design basis events.

By monitoring the cable over certain time intervals without damaging the cable, a shape determination of cable degradation with respect to operating time could be established to determine the rate at which the cable is aging.

An ideal instrument for determining the condition of the cable would need to meet the following requirements:

- no disturbance of cables or sample removal during testing,

- provide key indicators for determining structural integrity and electric functionality,

- no disconnection of equipment,

- usable during normal operation where appropriate,

- applicable to all materials,

- well-correlated with actual cable degradation,

- useable in areas of limited access,

- reproducible in different environments (e.g., temperature, humidity, vibration),

- cost-effective,

- able to detect defects at any location, and

- provide adequate time for corrective action to be taken before cable failure.

Currently, there are no techniques that can satisfy all of these requirements, but a wide range of methods have been evaluated for use in NPPs as part of a monitoring program (EPRI). Several laboratory tests are available for cable inspection; however, these require that a sample of the cable aged under the same conditions as the location of interest be available for testing. These tests do not generally fulfill all the listed requirements for one of two reasons: (1) the test may be destructive, meaning that the number of cable samples limits the frequency of the test; or (2) cable samples may not have experienced the same environmental stressors seen in inaccessible locations.

Standards for the test method have now been written for the most developed condition monitoring techniques. Table 3.1 lists the common methods either under development or in use for cable inspections. Most of the methods are appropriate for evaluation of aging degradation in laboratory studies and potentially for use in NPPs. 
Table 3.1. Most Common Methods Currently Considered Viable for Cable Inspection

\begin{tabular}{|c|c|c|c|}
\hline Visual/Tactile & Electrical & Mechanical & Chemical \\
\hline Thermography & $\begin{array}{l}\text { Frequency domain } \\
\text { reflectometry }\end{array}$ & Indenter & $\begin{array}{l}\text { Fourier transform } \\
\text { infrared spectroscopy }\end{array}$ \\
\hline Walk down & $\begin{array}{l}\text { Time domain } \\
\text { reflectometry }\end{array}$ & Elongation at break & $\begin{array}{l}\text { Oxidation induction } \\
\text { time }\end{array}$ \\
\hline \multirow[t]{6}{*}{ Borescope } & R TDR & Recovery time & \\
\hline & Insulation resistance & Sonic velocity & \\
\hline & $\begin{array}{l}\text { LCR (inductance, } \\
\text { capacitance, and } \\
\text { resistance) }\end{array}$ & & \\
\hline & Tan delta & & \\
\hline & Partial discharge & & \\
\hline & Line resonance analysis & & \\
\hline
\end{tabular}

The methods used for cable inspection currently can be broadly classed into visual/tactile, electrical, and mechanical testing methods. An alternative approach to categorizing these is in terms of screening and diagnostic techniques (Villaran and Lofaro 2010). A brief description of each of these methods follows.

Visual and tactile methods are the most common methods used for cable condition evaluation. Typically these are performed as part of walk-downs where the accessible length of the cable is inspected visually and/or by touch. Visual inspection can only determine if there is any physical damage or change in appearance of the cable. Tactile inspection by the person walking down the cables can also determine roughness or other tactile changes that would be out of the norm. While generally effective, these methods are applicable only to accessible sections of the cable. Enhanced visual inspection using a borescope may be used in areas that are difficult or impossible to visually inspect during a walk-down. The borescope illuminates the inspection area and assists in determining undetectable damage inside conduits or other remotely inaccessible spaces. The borescope can help in identifying water, contaminants, and electrical fault damage.

An alternative approach that also requires access (for line-of-sight operation) is infrared (IR) thermography that identifies regions of elevated temperatures in the cable that could be indicative of damage or accelerated aging. Both visual/tactile inspection and IR thermography are generally limited to specially trained and experienced users. Note that these methods are also applicable for in-situ inspection and are screening methods (i.e., can identify regions of concern on inspected cables, but may not be able to identify the mechanism at work or the amount of degradation in the insulation).

Electrical methods are diverse but fundamentally rely on changes in the electrical properties of the insulation and/or conductors for their assessment. Insulation test methods include insulation resistance, dielectric loss (or tan-delta), partial discharge, AC withstands, high-potential, and step voltage methods, none of which require access to the entire section of cable. Many of these methods are diagnostic in nature (i.e., can be used for degradation detection and may provide trendable data) and may be performed 
in-situ. The drawback is that some of the tests may damage the insulation due to the high voltages necessary. In addition, determining the location of the degradation may be difficult in most cases.

Other electrical inspection methods interrogate the condition of the conductor through reflectometry measurements, either in the frequency domain (FDR) or time-domain (TDR, R-TDR). Generally, timedomain methods transmit a pulse of energy down a cable from one end, which must be disconnected from the system for testing. The transmitted energy is reflected partially back when it encounters any change in electrical impedance along the cable. These changes may be due a termination, such as the far end of the cable, or faults along the length of the cable. The time necessary for the pulse to travel to the impedance change and reflect back to the open end of the cable can be used to determine the location of the impedance change; however, identification of changes requires accurate baseline data for comparisons. The pulse used to detect faults is very low power and non-destructive to the cables being investigated. Variations on this technique (which employs transmission line principles) include frequency-domain reflectometry (which applies swept frequency $\mathrm{CW}$ energy), line resonance analysis (LIRA; which also employs frequency domain analysis to identify changes in phase due to aging) and R-TDR. With the exception of LIRA, all reflectometry techniques require disconnecting the cable at one end, although the techniques are applicable to all low and medium voltage cables. In theory, reflectometry measurements are sensitive to faults in the conductor as well as in the surrounding insulation layer; however, the sensitivity to insulation aging is generally much lower than that for faults in the conductor.

Other testing techniques (including mechanical methods) are generally restricted to the laboratory (with the exception of the indenter method). The indenter method measures the compressive modulus of the material, which is the ratio of compressive stress to compressive strain. As the cables age, their insulators and jacketing materials will often harden, increasing the compressive modulus. It has been determined that compressive modulus provides an excellent indicator to the age and degradation rate of the material. While the indenter is slightly intrusive, it has been accepted by industry as a means of inspection. The testing is restricted to accessible cables only and on the outer surface of the jacket only. The method cannot be used on cables interior to a cable bundle for insulation measurements.

The elongation at break $(\mathrm{EAB})$ method is a destructive test that is often done in the laboratory to determine the age condition of the jacket and insulator based on their remaining ductility. The material ductility is a key indicator and changes based on the aging and different environmental stressors and correlates well in determining the remaining useful life of the material.

Oxidation induction time (OIT) is a measurement on the amount of oxidation that occurs when the material is exposed to a flowing oxygen environment at a constant temperature. The materials commonly have antioxidants compounded in them to help scavenge oxidizing species before damage can occur. However, these materials are consumed over time and the material begins to oxidize, which is part of the aging process. This technique requires small samples and is primarily used in the lab.

Note that all laboratory techniques require samples of the cable or insulation and are generally destructive in nature (i.e., the sample under test is destructively analyzed during the test). Table 3.2 summarizes the various inspection methods that are currently considered viable for detecting flaws and aging in cables. 
Table 3.2. Comparison of Cable Inspection Methods

\begin{tabular}{|c|c|c|}
\hline Inspection Method & Advantages & Disadvantages \\
\hline \multicolumn{3}{|c|}{ Visual and Tactile } \\
\hline Visual Inspection & Simple, fast, most commonly used & $\begin{array}{l}\text { Relies on experience, can't predict } \\
\text { remaining life }\end{array}$ \\
\hline Borescope & $\begin{array}{l}\text { Enhanced visualization technique for } \\
\text { accessing areas that are difficult or } \\
\text { impossible to visually inspect during } \\
\text { a walk down }\end{array}$ & $\begin{array}{l}\text { Relies on experience, can't predict } \\
\text { remaining life }\end{array}$ \\
\hline Infrared Thermography & $\begin{array}{l}\text { Elevated temperatures in cables that } \\
\text { could be areas of damage or } \\
\text { accelerated aging concerns }\end{array}$ & $\begin{array}{l}\text { Requires line of sight operation } \\
\text { and is limited to specially trained } \\
\text { users }\end{array}$ \\
\hline \multicolumn{3}{|c|}{ Electrical } \\
\hline $\begin{array}{l}\text { Time-Frequency Domain } \\
\text { Reflectometry }\end{array}$ & $\begin{array}{l}\text { Commonly used for determining the } \\
\text { condition of instrumentation, control } \\
\text { and power cables where they are } \\
\text { inaccessible }\end{array}$ & $\begin{array}{l}\text { Currently intrusive, requires } \\
\text { disconnecting the cables to install } \\
\text { instrumentation }\end{array}$ \\
\hline Insulation Resistance & $\begin{array}{l}\text { Commonly performed in industry to } \\
\text { determine the condition of the cable } \\
\text { insulation. }\end{array}$ & $\begin{array}{l}\text { Currently intrusive, requires } \\
\text { disconnecting the cables to install } \\
\text { instrumentation }\end{array}$ \\
\hline LCR & $\begin{array}{l}\text { Good for detecting changes in } \\
\text { electrical circuit (cable and } \\
\text { termination) by trending changes in } \\
\text { inductance, capacitance and } \\
\text { resistance }\end{array}$ & $\begin{array}{l}\text { Currently intrusive (requires } \\
\text { disconnecting cable at one end). } \\
\text { Does not indicate location or cause } \\
\text { of change in measurement }\end{array}$ \\
\hline Tan Delta & $\begin{array}{l}\text { Determines changes in insulation } \\
\text { (dielectric) properties by measuring } \\
\text { change in dielectric loss angle. Can } \\
\text { measure aging effects over entire } \\
\text { cable length }\end{array}$ & $\begin{array}{l}\text { Intrusive (requires decoupling both } \\
\text { ends). Single number from long } \\
\text { cable makes isolating location of } \\
\text { aging section difficult. Loss angle } \\
\text { may be trended however, single } \\
\text { measurement insufficient to } \\
\text { estimate remaining life }\end{array}$ \\
\hline Partial Discharge & $\begin{array}{l}\text { Good for determining voids or } \\
\text { defects in insulators of medium } \\
\text { voltage cables }\end{array}$ & $\begin{array}{l}\text { Test can damage the insulator with } \\
\text { localized heating that causes } \\
\text { degradation }\end{array}$ \\
\hline \multicolumn{3}{|c|}{ Mechanical } \\
\hline Indenter & $\begin{array}{l}\text { Compressive modulus is excellent } \\
\text { indicator to the age and degradation } \\
\text { rate of the material }\end{array}$ & $\begin{array}{l}\text { Slightly intrusive, restricted to } \\
\text { accessible cables only and the } \\
\text { outer surface of the jacket }\end{array}$ \\
\hline Recovery time & $\begin{array}{l}\text { Compressive test as function of time } \\
\text { to determine recover rate of applied } \\
\text { stress. Similar to indenter method for } \\
\text { determining age and degradation }\end{array}$ & $\begin{array}{l}\text { Slightly intrusive, restricted to } \\
\text { accessible cables only and the } \\
\text { outer surface of the jacket }\end{array}$ \\
\hline Elongation at Break & $\begin{array}{l}\text { High level of accuracy in } \\
\text { determining ductility and remaining } \\
\text { useful life }\end{array}$ & $\begin{array}{l}\text { destructive test, in laboratory } \\
\text { testing }\end{array}$ \\
\hline Sonic Velocity & $\begin{array}{l}\text { Acoustic velocity in materials change } \\
\text { as the modulus changes and could be } \\
\text { used to determine age and remaining } \\
\text { life }\end{array}$ & $\begin{array}{l}\text { Untested in cable configuration, } \\
\text { development required }\end{array}$ \\
\hline
\end{tabular}




\begin{tabular}{|l|l|l|}
\hline \multicolumn{2}{|c|}{ Chemical } \\
\hline $\begin{array}{l}\text { Fourier Transform Infrared } \\
\text { Spectroscopy }\end{array}$ & $\begin{array}{l}\text { Excellent method for identifying key } \\
\text { indicators of aging compared to } \\
\text { unaged materials }\end{array}$ & $\begin{array}{l}\text { Currently restricted to lab use, new } \\
\text { instruments are being developed. } \\
\text { Need database of unaged materials } \\
\text { for comparison of spectra }\end{array}$ \\
\hline Oxidation Induction Time & $\begin{array}{l}\text { Accurate method for determining } \\
\text { levels of antioxidants remaining and } \\
\text { oxidation state in polymers }\end{array}$ & Primarily used in the lab, intrusive \\
\hline
\end{tabular}




\subsection{NDE Research \& Development Roadmap for Evaluation of Aging Cables and Degradation in NPP for Determining Remaining Useful Life}

The purpose of the non-destructive evaluation R\&D Roadmap for Cables is to support the Materials Aging and Degradation (MAaD) R\&D pathway for the Light Water Reactor Sustainability (LWRS) program.

\subsection{NDE Cables Workshop}

A workshop was conducted to elicit expert judgment on cables. The focus of the workshop was to identify the technical gaps in detecting aging cables and predicting their remaining life expectancy. The workshop was held in Knoxville, Tennessee, on July 30, 2012, at Analysis and Measurement Services Corporation headquarters. As shown in Appendix A, the workshop was attended by 30 experts in materials, electrical engineering, and NDE instrumentation development from the NRC, DOE National Laboratories (Oak Ridge National Laboratory, Pacific Northwest National Laboratory, Argonne National Laboratory, and Idaho National Engineering Laboratory), universities, commercial NDE service vendors and cable manufacturers, and EPRI.

\subsection{Gaps in NDE Capabilities}

The processes used in the Cables Workshop to identify "Gaps in NDE Capabilities" are shown in Appendix B. The major emphasis of the workshop focused on the chemical changes in the material caused by the environment (thermal, radiation, and moisture); its relationship with changes in mechanical, physical, and electrical properties; and the current state-of-the-art in NDE techniques used for detecting aging and degradation of cables. The only technique currently accepted by industry to measure cable elasticity is the indentation measurement. All other NDE techniques are used to find flaws in the cable, but not to determine their current state of life expectancy. Figure 4.1 illustrates the place and importance of NDE technologies in being able to predict the remaining useful life of cables. 


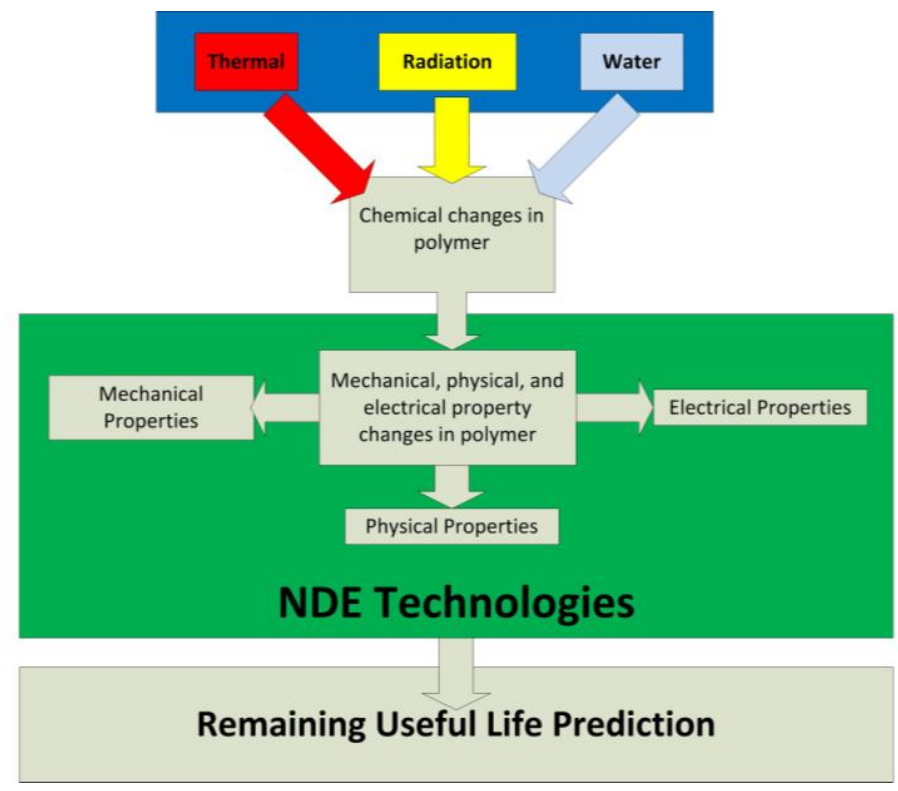

Figure 4.1. Usefulness of NDE in Predicting Remaining Cable Life

The experts brainstormed to identify the technical gaps for NDE. The gaps exist between what measurements materials experts want and the current NDE capability, (i.e. what do we want to be able to measure with NDE that we can't measure now?) Once gaps were identified and defined, the experts proposed NDE R\&D to close them. Table 4.1 shows the gaps in NDE technology between what NDE can currently measure versus what the materials experts would like it to measure.

Table 4.1. A Summary of the Main Gaps Identified

\begin{tabular}{|c|c|}
\hline Wanted & Gap \\
\hline \multicolumn{2}{|c|}{ Key Indicators for Measureable Changes in Materials Properties } \\
\hline $\begin{array}{l}\text { - Detection of early degradation of } \\
\text { insulation (or insulation degradation } \\
\text { products) } \\
\text { - Determine degradation in cable } \\
\text { insulation. } \\
\text { - Status of cable jacket and insulator } \\
\text { condition. } \\
\text { - Jacket/insulation degradation. } \\
\text { - Insulators and jacket material mechanical } \\
\text { property measurements that correlate to } \\
\text { aging state. } \\
\text { - Polymer weight loss (TGA) as a function } \\
\text { of various stressors or long-term } \\
\text { exposure environmental factors, e.g., } \\
\text { isothermal heating, voltage, radiation and } \\
\text { others to develop lifetime models. } \\
\text { Electrical properties (macro-scopic) of } \\
\text { ages insulation polymers (above aging } \\
\text { mechanisms) - include complex } \\
\text { sensitivity and breakdown strength. } \\
\text { - Jacket/insulation degradation state due to } \\
\text { thermal/rad aging remotely }\end{array}$ & $\begin{array}{l}\text { - Early detection and to enable tracking/prediction of remaining } \\
\text { life. } \\
\text { - No reliable, quantified NDE technique to detect and measure } \\
\text { degradation in cable insulation. } \\
\text { - Harder to determine status of the non-conductor components. } \\
\text { Needs to be easy and simple so NPPs will use. } \\
\text { - Quantification (i.e. assess detection sensitivity. Acceptance } \\
\text { criteria } \\
\text { - Currently not adopted in the US according to EPRI representative. } \\
\text { - Are there other methods to do this? Data correlation? } \\
\text { Sensitivity? Broad materials Use? What are the limitations on } \\
\text { - LiRA? } \\
\text { Measurement methods for at-a-distance insulation } \\
\text { sensitivity/breakdown strength assessment. } \\
\text { - Remote evaluation of insulation/jacket degradation to assess level } \\
\text { of degradation. Ability to identify jacket degradation from other } \\
\text { compounding factors that also impact remote measurement. } \\
\text { - The gap is that there needs to be a way to quantify in-situ the } \\
\text { condition of the cables. Do the cable properties change } \\
\text { significantly from laboratory conditions to the operation } \\
\text { environment and is this a concern. Are test results of cold samples } \\
\text { non-conservative. Most plants will be performing these }\end{array}$ \\
\hline
\end{tabular}




\begin{tabular}{|c|c|}
\hline Wanted & Gap \\
\hline $\begin{array}{l}\text { - Impact of temperature/radiation on the in- } \\
\text { situ or laboratory tests. }\end{array}$ & $\begin{array}{l}\text { assessments at cold shut down and not during operation. So even } \\
\text { in-situ tests may not be conservative. What about operating } \\
\text { equipment that creates hot spots, if they are not operating during } \\
\text { testing then it may not be an accurate picture. }\end{array}$ \\
\hline \multicolumn{2}{|c|}{$\begin{array}{l}\text { Advance State-of-the-Art in Current Cable NDE Methods and Develop New and Transformational NDE } \\
\text { Methods }\end{array}$} \\
\hline $\begin{array}{l}\text { - Electrical method to determine age of } \\
\text { cable would be even better if can be no } \\
\text { contact with cable. } \\
\text { - Condition monitoring data (electrical, } \\
\text { mechanical, dielectric tests) - acceptance } \\
\text { criteria/performance. } \\
\text { - Measurement of the amount of } \\
\text { thermal/radiation impact on specific } \\
\text { location with electrical based tests. } \\
\text { - Test of XLPE that may be used in-situ. } \\
\text { - In-situ measurement/monitoring of cable } \\
\text { insulation damage degradation. } \\
\text { - In-situ techniques for cable condition } \\
\text { monitoring (particularly cable insulation } \\
\text { material. } \\
\text { - When cables are installed they are often } \\
\text { pulled into place much like an un- } \\
\text { intentional EAR. Is there a way to } \\
\text { identify, in-situ, whether a cable has } \\
\text { already been mechanically 'stressed'? }\end{array}$ & $\begin{array}{l}\text { - Need to be able to distinguish relatively moderate aging such as } \\
\text { what would be seen with } 50 \% \text { retention of elongation. Non- } \\
\text { contact would be best, but many cable are not accessible } \\
\text { - Data needed to determine when corrective action should be taken. } \\
\text { Can use a representative environment or worst case environment. } \\
\text { (hi T, Hi Rad to combination etc.) } \\
\text { - Correlation of the amount of thermal/radiation aging with } \\
\text { electrical parameter results. } \\
\text { - A possibility is to heat the XLPE locally and do a mechanical test. } \\
\text { - Existing cable testing methods are all aimed at detecting damage } \\
\text { (conductor or insulator) after the problem arises and not predicting } \\
\text { future sate. Need to develop a robust in-situ/on-line monitoring } \\
\text { method for detection of insulator damage/degradation and predict } \\
\text { its remaining useful life. } \\
\text { - Need to clearly know what cables are important for cable aging } \\
\text { management and cable condition monitoring. Some people say } \\
\text { I\&C cables are predominately the ones to worry about, and other } \\
\text { mediums and high voltage cables are not of regulatory other } \\
\text { concern. } \\
\text { - Is there a set of tests that would identify a 'weaker' cable that has } \\
\text { not yet developed a fault? Is a weakened cable more likely to } \\
\text { develop a fault in the 'weak' area? Do the electrical properties } \\
\text { change through mechanical stressing and, if so, how? }\end{array}$ \\
\hline \multicolumn{2}{|c|}{ Develop Models for Predicting Remaining Useful Life of Cables Based on Condition Indices } \\
\hline $\begin{array}{l}\text { - Qualified condition of cable insulation. } \\
\text { Best measured by indenter first and EAB } \\
\text { second. Can be used for prognostic } \\
\text { planning of remaining useful life. } \\
\text { - Service life prediction. } \\
\text { - All measurements in-situ and laboratory. } \\
\text { - Independent measurements of the bulk } \\
\text { material properties of the cable jacket and } \\
\text { insulation material (e.g., elastic/complex } \\
\text { modulus) and how those measurements } \\
\text { correspond to the cables ability to } \\
\text { withstand a LOCA event or if it should } \\
\text { be replaced. } \\
\text { - Verification that cables will survive } \\
\text { accident condition (LOCA, etc.) at end of } \\
\text { 40-60 year life. } \\
\text { - NDE data to correlate to indenter } \\
\text { modulus with more specific acceptable } \\
\text { criteria. } \\
\text { - Pre-failure condition(s) of cabling } \\
\text { including insulation. }\end{array}$ & $\begin{array}{l}\text { - We need to correlate in-situ electrical measurements including } \\
\text { FDR, IR, TDR and LCR to CM such as indenter and EAB. . US } \\
\text { NPPs currently do not use cable deposits for sacrificial sample in } \\
\text { areas of concern. } \\
\text { - Models not available for accurate service life prediction } \\
\text { - Plants need the data converted to readily understandable and } \\
\text { easily used acceptance criteria. Plant personnel will not use } \\
\text { techniques and data that require research effort to assess a cable. } \\
\text { - It is not significantly well understood how current NDE } \\
\text { techniques for measuring the condition of the cable correspond to } \\
\text { whether or not it will survive in a design basis accident or if the } \\
\text { cable is still "good" to continue using. } \\
\text { - Predict cable performance under accident conditions. } \\
\text { - The indenter modulus strongly correlates to destructive, } \\
\text { mechanical test such as EAB (which does not have a clear defined } \\
\text { acceptable criteria due to it is a very polymer specific test). Strong } \\
\text { NDE tests are needed for correlation with more specific } \\
\text { acceptable criteria. } \\
\text { - Ability to derive higher probability of determining condition from } \\
\text { complementary measurements. Ability to utilize existing } \\
\text { information to predict remaining useful life, or, time to failure. }\end{array}$ \\
\hline
\end{tabular}


The experts identified $R \& D$ to address these gaps and then prioritized the list. Figure 4.2 shows how the experts ranked the NDE R\&D needs. The voting and ranking of the proposal concepts were discussed with the group and core research themes emerged that were directed towards achieving the objective of determining the condition and remaining useful life of aging cables in light water reactors.

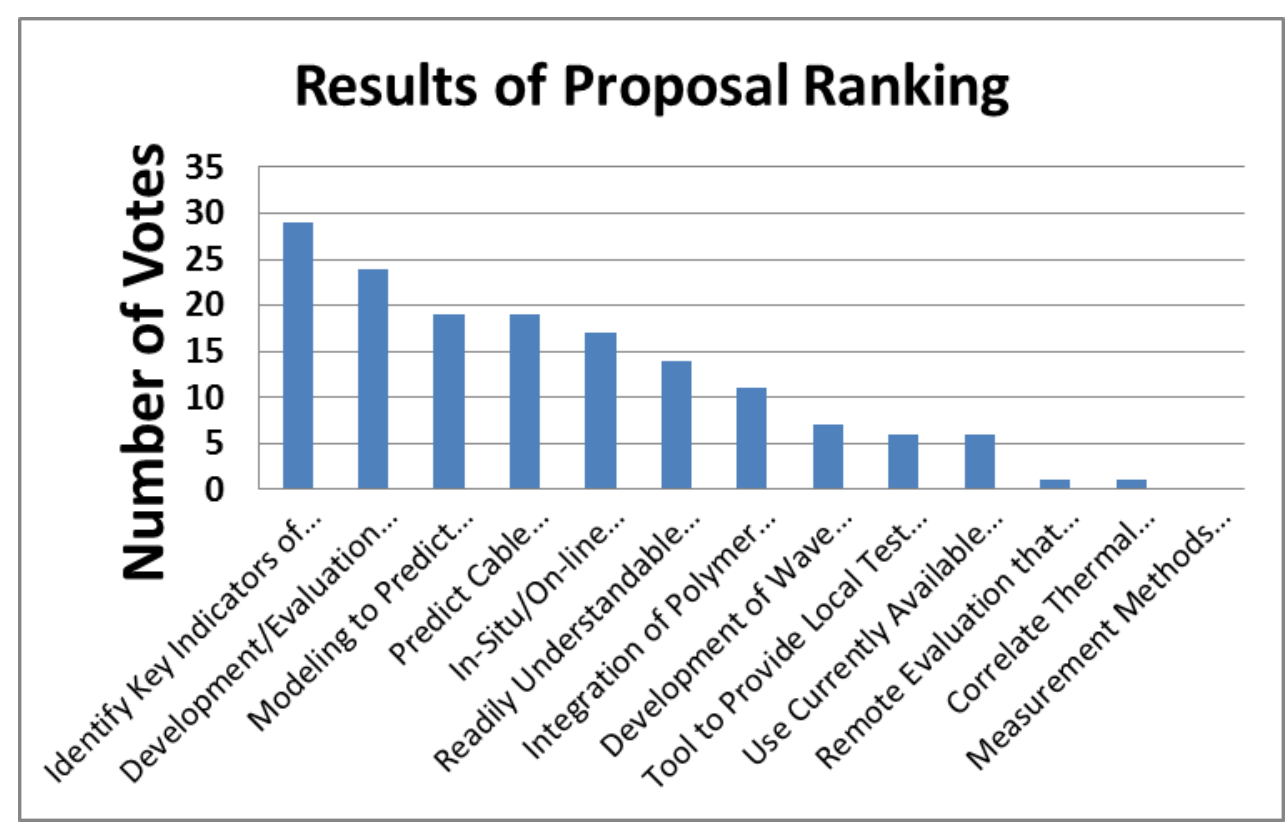

Figure 4.2. Proposal Ranking by the Working Group

The results from the workshop identified three areas of importance:

1. Determine key indicators of cable aging that correlate with measureable changes in material properties at macroscopic scale.

2. Advance state-of-the-art in current cable NDE methods and/or develop new and transformational NDE methods to determine cable condition. The data for these developments would be from samples generated from laboratory cable aging experiments as well as field samples.

3. Develop models for predicting remaining useful life of cables based on condition indices. The data for these models would come from existing databases, the information generated in topics 1 and 2, and any other available (and relevant) sources.

Figure 4.3 shows how the proposed NDE R\&D supports being able to evaluate the condition of cables and estimate the remaining useful life (RUL). The numbers shown in the figure are voting of the experts for the various proposed NDE R\&D activities. 

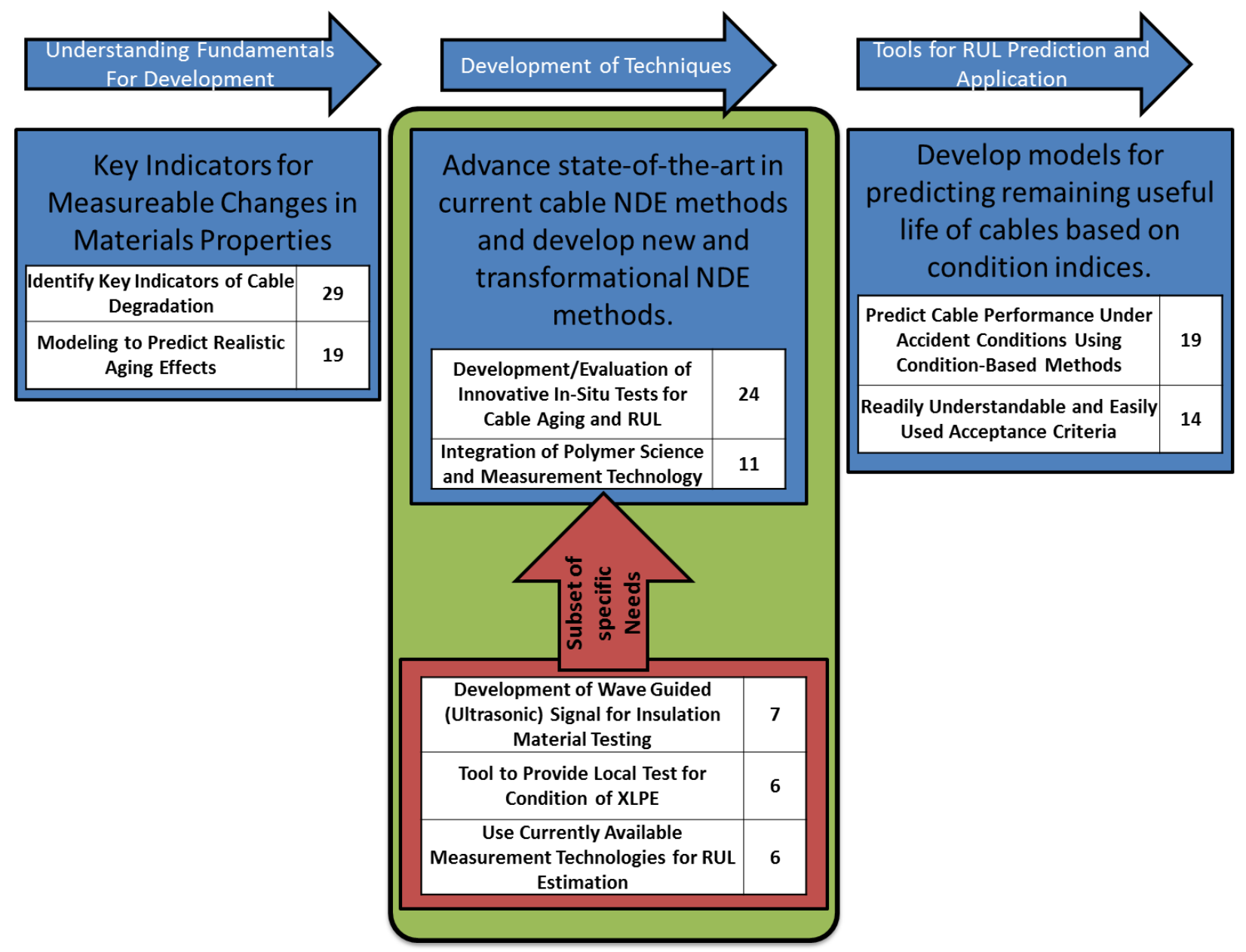

Figure 4.3. Illustration of Flow of Research for NDE Development and RUL Models

The most important criteria for cable performance is its ability to withstand a design basis accident. Currently, there is no single NDE technique that can satisfy all of the requirements needed for making a life expectancy determination, but a wide range of methods have been evaluated for use in NPPs as part of a continuous evaluation program. The commonly used methods are indentation and visual inspection, but are only suitable for easily accessible cables. Several NDE techniques utilizing electrical techniques are in use today for flaw detection, but there are none that can predict the life of a cable.

\subsection{Need for Determining Key Aging Indicators}

In order to determine appropriate NDE technology or the need for new technology, the key indicators of cable aging need to be better understood so that correlations with measureable changes in material properties at a macroscopic scale can be measured with the appropriate sensitivity. There is a need to combine polymer science with measurement knowledge to arrive at a practical means to identify and locate problems in insulation material along the installed cable. Depending on the insulating material type, the environmental effects can happen at different degradation rates and mechanisms that change the properties. For example, ethylenepropylene rubber (EPR) can undergo thermal or radiation degradation at different rates depending on temperature or radiation dose rate. However, cross-linked polyethylene 
has been shown in laboratory experiments to have an inverse temperature effect that ages the cable faster at lower temperatures with radiation. Some EPRs have also shown inverse temperature effects.

Existing data from cable aging studies and decommissioned reactor cables need to be gathered to develop an understanding of the key indicators of degradation and how they relate to the change in properties. Several aging models have been developed for aging and degradation, but the models for predicting accelerated aging at various times and temperature are based on Arrhenius rate equations and often don't correlate well due to non-linearity at lower temperatures.

Based on what is known about accelerated aging, testing coupled with aging experiments would be used to look for key indicators of change. Various types of electrical measurements would be needed to characterize the material's electrical properties. These measurements would be completed on calibrated exposed samples as well as on field samples. The data set generated from various materials, cable system configurations, and exposure testing will be available to the NDE measurement community to aid in the development of existing or new NDE techniques and prognostic models that are able to predict the remaining useful life.

It is expected that test and acceptance criteria will be developed for instrumentation developers and end-users of NDE equipment for known material conditions and degradation targets that can guide the NDE community towards useful life predictions, as well as assessment of functional performance and accident survivability. It is also expected that demonstrating a strong correlation between aging and key indicators in the material that affect electrical and material property parameters will enable the NDE community to work towards sensitive techniques.

\subsection{Need for Developing Models for Predicting Remaining Useful Life of Cables Based on Condition Indices}

With key NDE advanced methods or new technologies, there is a need for developing models for predicting remaining useful life of cables based on their condition. RUL models would use the NDE measurements and have the ability to correlate and predict with accuracy changes in physical, mechanical, or electrical properties of cable insulators and jacket materials. This would be important information to the LWRS program. The data for these models would come from existing databases and information generated in previous gap proposals in the workshop.

The NDE measurements must contribute to estimating the remaining useful life of cable materials. To achieve this, predictive models of degradation accumulation as a result of aging are needed. These models will need to be correlated with NDE measurements. This could be achieved using existing databases of cable aging and measurement. The goal is to define condition indices that represent the current condition of the cable and insulation (based on NDE measurements), and use this information in combination with the predictive models, environmental conditions that the cable is subjected to, and established end-of-life criteria, to assess remaining useful life.

\subsection{Need to Survey Availability of Aged Cables for NDE Samples}

For studies planned in this program, an adequate collection of cable samples plays a key role. Cable samples with well-defined environmental and aging conditions can be used as a resource for developing, 
improving, and evaluating various NDE cable measurement methods and prognostic models. The cable material properties, cable location, and relevant environmental conditions the cable would have been subjected to would be a valuable asset for referencing the most realistic condition cable available.

Reference cables need to reflect the testing problem as realistically as possible in regards to the test method applied to them. Test sample sections should be as similar as possible to the actual cable conditions commonly seen in NPPs in terms of how they interact with the particular test method.

Artificial test cable test sections allow the isolation of certain testing problems as well as the variation of certain parameters. Because of the controlled conditions in the laboratory, the number of unknown variables can be decreased, which makes it possible to focus on key indicators of aging cables, investigate them in detail, and gain further information on the capabilities and limitations of NDE methods. However, the materials used for the fabrication of the artificial test sections may not be representative of the original cable fabricated some forty to fifty years ago. Older cable insulator formulations have been improved upon and several companies who supplied cables to NPPs are no longer in business; therefore, some cable materials may be not be available anymore.

Furthermore, a detailed documentation and testing program must be associated with the accelerated aging of any new artificial test sections. It should include:

- Augmented monitoring including (to be defined depending on the amount of degradation to be studied): temperature, humidity, strain (local/structural scale), resistivity, elasticity, etc.

- Significant material testing of cable material properties including mechanical properties (strength, elasticity, density...) and electrical properties (resistivity, dielectric constant, ...). Additional control samples might also be required.

To minimize artifacts caused by boundary effects, the dimensions of the specimens should not be too compact. The exact size will depend on the NDE method used. There are practical limitations because such lengths are placed in laboratories and, in most cases, will have to be movable.

Available samples from decommissioned power plants would also be beneficial to the program. 


\subsection{Conclusions}

The motivation for this $R \& D$ roadmap comes from the need to address the aging management of incontainment cables at nuclear power plants. Safety-related power, instrumentation, and control cables must retain integrity and perform during not only normal service conditions, but also for design basis accident conditions. Therefore, it is of significant importance to be able to measure the remaining useful life of the existing cables.

With nearly $1000 \mathrm{~km}$ of power, control, instrumentation, and other cables typically found in a NPP, it would be a significant to nearly impossible undertaking to inspect all of the cables with currently available methods. Degradation of the cable jacket, electrical insulation, and other cable components are key issues for assessing the ability of the currently-installed cables to operate safely and reliably for another 20 to 40 years beyond the initial operating license. The development of NDE techniques and prognostic models that could assist in determining their current state of condition and/or the remaining life expectancy of cables would be of significant interest. The ability to non-destructively determine material and electrical properties minimal disturbance to the cables or connections is essential.

The major emphasis of the workshop was on the chemical changes in the cable materials caused by the environment (thermal, radiation, and moisture); its effect on mechanical, physical, and electrical property changes; and the current state-of-the-art NDE techniques that are used for cable age detection. The only current technique accepted by industry is to measure cable elasticity by indentation measurement. All other NDE techniques are used to find flaws in the cable and not to determine their current overall health or remaining useful life.

The workshop identified three core proposals and one sample collection activity that could be completed in a six-year time frame. The individual proposals range from three to four years depending on their complexity and level of effort required to complete the tasks (Table 5.1). The first proposal is to better determine the key indicators of cable aging that result in measureable changes in the material properties at macroscopic scales. The second is to advance the state of the art in cable NDE methods by exploring advances in currently available methods while also exploring emerging techniques for cable

NDE. The third proposal idea is to develop models to predict the remaining useful life of cables based on NDE results, condition indices, and an understanding of aging and degradation growth in cable materials. Assembling a comprehensive collection of aged cable samples will support all the proposed R\&D projects.

The paths forward for specific project details include:

1. Need for Determining Key Aging Indicators

In order to be able to make a determination on the appropriate NDE technology or the need for a new technology, a determination of the key indicators of cable aging needs to be better understood so correlations with measureable changes in material properties at macroscopic scale can be measured with the right sensitivity and measurement technique. There is a need to combine polymer science with measurement knowledge to arrive at a practical means to identify and locate problems in insulation material along the installed cable. 
2. Need for Advancing the State-of-the-Art in Cable NDE Methods and Develop New and Transformational NDE Methods

With the determination of key indicators, advances in current state-of-the-art cable NDE methods or the development of new and transformational NDE methods can be considered for closing the gap with measuring material properties. There is a need for non-invasive methods that are capable of measurements in discrete and difficult to access locations. In order to evaluate any new or advanced NDE method, the need to have laboratory and field aged material samples for experimentation is required for determining sensitivity for identifying the key indicators to aging.

3. Need for Developing Models for Predicting Remaining Useful Life of Cables Based on Condition Indices.

The NDE measurements should provide information about the cable condition and health to prognose the remaining useful life in the cable. To achieve this, predictive models of degradation accumulation as a result of aging are needed. These models will need to be correlated with NDE measurements, which may be possible using existing databases of cable aging and measurement. The goal is to define condition indices that represent the current condition of the cable and insulation (based on NDE measurements), and use this information in combination with the predictive models, environmental conditions that the cable is subjected to, and established end-oflife criteria, to assess remaining useful life.

\section{Need to Survey Availability of Aged Cables for NDE Samples}

The material types and cable systems are well known and documented in NPP. Accelerated aging studies have been performed in the past and their current limitations are known. However, having available naturally aged cables in their known environmental conditions would be significant for comparing artificially aged samples to the naturally aged samples with NDE techniques. This would provide the most realistic assessment of NDE technologies and their current limitations.

The initial work needs to begin in the materials space and integrate into the second project as soon as possible. Evaluating current NDE techniques with respect to sensitivity to changes in material properties due to aging, along with assessment of emerging or alternative NDE methods is needed. The third proposal concept works with either the state of the art or newly developed NDE technique and correlates the data measurements with a model for determining the expected remaining life based on NDE measurements and the operating environment. This will allow decision makers to determine the state of the cables in an NPP and the investment that will be required for life extension of these cables. The collection of existing data and cable samples will be an ongoing activity, which will support all the initiated $R \& D$ projects. 
Table 5.1. Summary of proposed research projects and timeline for completion.

\begin{tabular}{|c|c|c|c|c|c|c|c|c|c|c|c|c|c|c|c|c|c|c|c|c|c|c|c|c|c|c|c|}
\hline \multirow{2}{*}{10} & \multirow{2}{*}{ Proposal } & \multicolumn{3}{|c|}{2013} & \multicolumn{4}{|c|}{2014} & \multicolumn{3}{|c|}{2015} & \multicolumn{4}{|c|}{2016} & \multicolumn{4}{|c|}{2017} & \multicolumn{4}{|c|}{2018} & \multicolumn{4}{|c|}{2019} \\
\hline & & \begin{tabular}{|l|l|}
$a 1$ & $a$ \\
\end{tabular} & \begin{tabular}{l|l|}
$\alpha_{2}$ & $Q_{3}$ \\
\end{tabular} & $a 4$ & $a_{1}$ & $\begin{array}{ll}02 \\
\end{array}$ & \begin{tabular}{|c|}
${ }_{3}$ \\
\end{tabular} & Q4 & $a_{1}$ & \begin{tabular}{|l|l|}
$Q_{2}$ & $Q_{3}$ \\
\end{tabular} & a4 & $Q_{1}$ & $a_{2}$ & a. & $a^{4}$ & Q1 & \begin{tabular}{|l|}
$a_{2}$ \\
\end{tabular} & \begin{tabular}{l|l}
${ }_{0.3}$ & \\
\end{tabular} & Q4 & a1 & a.2 & \begin{tabular}{l|l}
${ }_{3}$ \\
\end{tabular} & Q4 & $a_{1}$ & $Q_{2}$ & $a_{3}$ & Q4 \\
\hline 1 & $\begin{array}{l}\text { Determining key indicators of cable ageing that } \\
\text { correlate with measureable changes in material } \\
\text { properties at macroscopic scale }\end{array}$ & & & & & & & & & & & & & & & & & & & & & & & & & & \\
\hline 2 & $\begin{array}{l}\text { Advance state-of-the-art in current cable NDE } \\
\text { methods and develop new and } \\
\text { transformational NDE methods. }\end{array}$ & & & & & & & & & & & & & & & & & & & & & & & & & & \\
\hline 3 & $\begin{array}{l}\text { Develop models for predicting remaining } \\
\text { useful life of cables based on condition indices. }\end{array}$ & & & & & & & & & & & & & & & & & & & & & & & & & & \\
\hline
\end{tabular}




\subsection{Bibliography}

Golay MW and JH Moinzadeh. 1986. Extending the Life of Nuclear Power Plants: Technical and Institutional Issues. MIT-EL86-003, Massachusetts Institute of Technology, Cambridge, Massachusetts.

IAEA. 2004. Management of Life Cycle and Aging at Nuclear Plants: Improved I\&C Maintenance. IAEA-TECDOC-1402, International Atomic Energy Agency, Vienna, Austria.

Kim J-S. 2005. "Evaluation of Cable Aging Degradation Based on Plant Operating Condition." Journal of Nuclear Science and Technology 42(8):745-753.

Bates DJ, SR Doctor, PG Heasler and E Burck. 1987. Stainless Steel Round Robin Test: Centrifugally Cast Stainless Steel Screening Phase. NUREG/CR-4970, PNL-6266, PISC III Report No. 3, U.S. Nuclear Regulatory Commission, Washington, D.C.

Chockie LJ. 1981. "PVRC Round Robin Ultrasonic Program, Results and Assessment of Reliability." In Nondestructive Evaluation in the Nuclear Industry -- 1980, pp. 361-379. February 11-13, 1980, Salt Lake City, Utah. American Society for Metals, Metals Park, Ohio.

Chockie LJ. 1985. "Section XI of the ASME Code A New Approach to Qualifying Procedures and Personnel." In 7th International Conference on NDE in the Nuclear Industry, pp. 83-86 Grenoble, France.

Doctor SR, P Lemaitre and S Crutzen. 1995. "Austenitic Steel Piping Testing Exercises in PISC." Nuclear Engineering and Design 157(1-2):231-44.

Doctor SR. 1984. "NDE Reliability Assessment." In Non-Destructive Examination for Pressurised Components, pp. 323-335. August 30-31, 1983, Monterey, California. Elsevier Applied Science Publishers, London.

Doctor SR. 2007. "Nuclear Power Plant NDE Challenges - Past, Present, and Future." In Review of Progress in Quantitative Nondestructive Evaluation, pp. 17-31. July 30-August 4, 2006, Portland, Oregon. DOI 10.1063/1.2717950. American Institute of Physics, Melville, New York.

EPRI. 1994. Low-Voltage Environmentally-Qualified Cable License Renewal Industry Report; Revision 1. TR-103841, Electric Power Research Institute (EPRI), Palo Alto, California.

EPRI. 2008c. TR-105696-R11 (BWRVIP-03) Revision 11: BWR Vessel and Internals Project, Reactor Vessel and Internals Examination Guidelines TR-1016584, Electric Power Research Institute, Palo Alto, California.

EPRI. 2011c. Materials Reliability Program: Pressurized Water Reactor Internals Inspection and Evaluation Guidelines (MRP-227-A) TR-1022863, Electric Power Research Institute, Palo Alto, California.

Fong JT. 1986. NDE Reliability through Round Robin Testing: Presented at the 4th National Congress on Pressure Vessels and Piping Technology, Portland, Oregon, June 19-24, 1983 and the 1986 Pressure 
Vessels and Piping Conference and Exhibition, Chicago, Illinois, July 20-24, 1986. American Society of Mechanical Engineers, New York.

Gazdzinski RF, WM Denny, GJ Toman and RT Butwin. 1996. Aging Management Guideline for Commercial Nuclear Power Plants - Electrical Cable and Terminations. SAND 96-0344, Sandia National Laboratories, Albuquerque, New Mexico.

Gillen KT, RA Assink and R Bernstein. 2005. Nuclear Energy Plant Optimization (NEPO) Final Report on Aging and Condition Monitoring of Low-Voltage Cable Materials. SAND2005-7331, Sandia National Laboratories, Albuquerque, New Mexico.

Griffith G, R Youngblood, J Busby, B Hallbert, C Barnard and K McCarthy. 2012. Light Water Reactor Sustainability Program Integrated Program Plan. INL/EXT-11-23452, Idaho National Laboratory, Idaho Falls, Idaho.

IAEA. 2004. Management of Life Cycle and Aging at Nuclear Plants: Improved I\&C Maintenance. IAEA-TECDOC-1402, International Atomic Energy Agency, Vienna, Austria.

Miller C. 2008. Nondestructive Evaluation: A Review of NDE Performance Demonstrations - NDE Round Robin Report. Report No. 1016969, Electric Power Research Institute, Palo Alto, California.

Nichols R and N McDonald. 1987. "An Introduction to the PISC II Project--Programme for the Inspection of Steel Components." British Journal of Nondestructive Testing 29(4):223-227.

Singh R. 2000. Three Decades of NDI Reliability Assessment. Report No. Karta-3510-99-01, Karta Technology, Inc., San Antonio, Texas.

Villaran M and R Lofaro. 2009. Condition Monitoring of Cables, Task 3 Report: Condition Monitoring Techniques for Electric Cables. BNL-90735-2009-IR, Brookhaven National Laboratory, Upton, New York.

Willetts AJ and FV Ammirato. 1987. "Objectives and Techniques for Performance Demonstration of InService Examination of Reactor Pressure Vessels." In Performance and Evaluation of Light Water Reactor Pressure Vessels, pp. 79-86. June 28-July 2, 1987, San Diego, California. 


\subsection{References}

10 CFR 50.55a. 2007. "Codes and Standards." Code of Federal Regulations, U.S. Nuclear Regulatory Commission, Washington, D.C. Available at http://www.nrc.gov/reading-rm/doc-

collections/cfr/part050/part050-0055a.html.

Bond LJ. 1999. "Predictive Engineering for Aging Infrastructure." In Nondestructive Evaluation of Utilities and Pipelines III, Proceedings of SPIE, pp. 2-13. March 4, 1999, Newport Beach, California.

Bond LJ, SR Doctor and TT Taylor. 2008. Proactive Management of Materials Degradation - A Review of Principles and Programs. PNNL-17779, Pacific Northwest National Laboratory, Richland, Washington.

Chockie AD, KA Bjorkelo, TE Fleming, WB Scott and WI Enderlin. 1991. Maintenance Practices to Manage Aging: A Review of Several Technologies. PNL-7823, Pacific Northwest Laboratory, Richland, Washington.

Diaz NJ. 2004. The 3rd Annual Homeland Security Summit; Session on, "The Best-Laid Plans: A Case Study in Preparedness Planning": The Very Best-Laid Plans (the NRC's Defense-in Depth Philosophy). U.S. Nuclear Regulatory Commission. Washington, D.C. Available at http://www.nrc.gov/reading$\mathrm{rm} /$ doc-collections/commission/speeches/2004/s-04-009.html.

Gregor F and A Chockie. 2006. Performance Monitoring of Systems and Active Components. CGI Report 06:21, Chockie Group International, Inc., Seattle, Washington.

IAEA. 2000. Assessment and Management of Aging of Major Nuclear Power Plant Components Important to Safety: In-containment Instrumentation and Control Cables. Volume I. IAEA-TECDOC1188, International Atomic Energy Agency, Vienna, Austria.

NRC. 2001. Generic Aging Lessons Learned (GALL) Report. NUREG-1801, U.S. Nuclear Regulatory Commission, Washington, D.C.

NRC. 2005a. Generic Aging Lessons Learned (GALL) Report - Summary. NUREG-1801, Vol. 1, Rev. 1, Office of Nuclear Reactor Regulations, U.S. Nuclear Regulatory Commission, Washington, D.C.

NRC. 2005b. Generic Aging Lessons Learned (GALL) Report - Tabulation of Results. NUREG-1801, Vol. 2, Rev. 1, Office of Nuclear Reactor Regulations, U.S. Nuclear Regulatory Commission, Washington, D.C.

NRC. 2010a. Final Report - Standard Review Plan for Review of License Renewal Applications for Nuclear Power Plants. NUREG-1800, Rev. 2, U.S. Nuclear Regulatory Commission, Washington, D.C.

NRC. 2010b. Generic Aging Lessons Learned (GALL) Report - Final Report. NUREG-1801, Rev. 2, Office of Nuclear Reactor Regulations, U.S. Nuclear Regulatory Commission, Washington, D.C.

NRC. 2011. Information Digest, 2011-2012. NUREG-1350, Vol. 23, U.S. Nuclear Regulatory Commission, Washington, D.C.

Villaran M and R Lofaro. 2010. Essential Elements of an Electric Cable Condition Monitoring Program. NUREG/CR-7000; BNL-NUREG-90318-2009, U.S. Nuclear Regulatory Commission, Washington, D.C. 


\section{Appendix A}

\section{Cable Workshop Participants}




\section{Appendix A}

\section{Cable Workshop Participants}

\begin{tabular}{|clc}
\hline 1 & Sasan Bakhtiari & ANL \\
\hline 2 & Leonard Bond & Iowa State University \\
3 & Nicola Bowlers & Iowa State University \\
4 & David Brenchley & PNNL- Facilitator \\
5 & Dwight Clayton & ORNL \\
6 & Jamie Coble & PNNL \\
7 & Hash Hashemian & AMS \\
8 & Wes Hines & UTK \\
9 & Robert Konnik & Rockbestos Cable \\
10 & John Lareau & WesDyne \\
11 & John Lindberg & EPRI \\
12 & John Popovics & University of Illinois \\
13 & Pradeep Ramuhalli & PNNL \\
14 & Sheila Ray & NRC \\
15 & Tim Roney & INL \\
16 & Thomas Rosseel & ORNL \\
17 & Kevin Simmons & PNNL \\
18 & Cy Smith & ORNL \\
19 & Gary Toman & EPRI \\
20 & Venu Varma & ORNL \\
21 & Josh Cole & AMS \\
22 & Dara Cummins & AMS \\
23 & Craig Harris & AMS \\
24 & Mehrad Hashemian & AMS \\
25 & Chad Kiger & AMS \\
26 & Jonathan Ledlow & AMS \\
27 & Chris Lowe & AMS \\
28 & Bryan McConkey & AMS \\
29 & Ryan O'Hagan & AMS \\
30 & Casey Sexton & AMS \\
\hline & & \\
\hline
\end{tabular}




\section{Appendix B}

\section{Workshop Process}




\section{Appendix B}

\section{Workshop Process}

The focus of the workshop was to identify the technical gaps in using NDE to detect aging and degradation in cables to support predicting their remaining life expectancy. The workshop was held in Knoxville, Tennessee, on July 30, 2012, at Analysis and Measurement Services Corporation (AMS) headquarters. Dr. H. M. Hashemian, President of AMS, hosted the workshop which was attended by 30 experts.

\section{B.1 Identify Gaps}

The participants were asked to identify gaps between the "measurements wanted" by materials experts and the "current NDE capabilities?" What are the gaps between the "measurements wanted" by materials experts and the "current NDE capabilities?" What do we need to be able to do with NDE that we can't do now? Gaps are the difference between NDE can do now versus what materials experts want it to do. The following gaps were identified through brainstorming; the gaps were assigned to one of three working groups.

Table B.1. Brainstorming Gaps Assigned to Group 1

\begin{tabular}{|l|l|}
\hline \multicolumn{2}{|c|}{ Group 1 - Cable } \\
\hline Measurements wanted: & $\begin{array}{l}\text { Detection of early degradation of insulation (or insulation degradation products) } \\
\text { e.g., Impedance? }\end{array}$ \\
\hline Current NDE Capability: & $\begin{array}{l}\text { Reflectometry detects macro damage and/or degradation. Current methods detect } \\
\text { "fault" not pre-cursors. }\end{array}$ \\
\hline The GAP: & Early Detection and to enable tracking/prediction of remaining life. \\
\hline & \multicolumn{1}{|c|}{ ROBERT KONNIK } \\
\hline Measurement wanted: & $\begin{array}{l}\text { Electrical method to determine age of cable would be even better if can be no } \\
\text { contact with cable }\end{array}$ \\
\hline Current NDE Capability & May tell cracking or severe aging. Have to lift leads to test. \\
\hline The GAP: & $\begin{array}{l}\text { Need to be able to distinguish relatively moderate aging such as what would be } \\
\text { seen with 50\% retention of elongation. Non-contact would be best, but many cable } \\
\text { are not accessible. }\end{array}$ \\
\hline & \multicolumn{1}{c}{ JOHN LINDBERG } \\
\hline Measurements wanted: & Determine degradation in cable insulation \\
\hline Current NDE Capability & Visual examination \\
\hline The GAP: & $\begin{array}{l}\text { No reliable, quantified NDE technique to detect and measure degradation in cable } \\
\text { insulation. }\end{array}$ \\
\hline
\end{tabular}




\begin{tabular}{|c|c|}
\hline \multicolumn{2}{|r|}{ Group 1 - Cable } \\
\hline \multicolumn{2}{|r|}{ JOHN POPOVICS } \\
\hline Measurements wanted: & Changing properties of insulating materials surrounding conducers \\
\hline Current NDE Capability: & Infrared? (I am not sure of capabilities) \\
\hline The GAP: & I am not knowledgeable enough to suggest. \\
\hline \multicolumn{2}{|r|}{ BRYAN McCONKEY } \\
\hline Measurements wanted: & $\begin{array}{l}\text { Qualified condition of cable insulation. Best measured by indenter first and EAB } \\
\text { second. Can be used for prognostic planning of remaining useful life. }\end{array}$ \\
\hline Current NDE Capability & $\begin{array}{l}\text { Indenter is non-destructive and in-situ but requires access to harsh } \\
\text { environments/areas of concern. EAB is a destructive lab test that requires a } \\
\text { sacrificial sample of the field cable or an equivalent representative sample. }\end{array}$ \\
\hline The GAP: & $\begin{array}{l}\text { We need to correlate in-situ electrical measurements including FDR, IR, TDR and } \\
\text { LCR to CM such as indenter and EAB. AMS is exploring this with laboratory } \\
\text { research under a DOE research grant. US NPPs currently do not use cable deposits } \\
\text { for sacrificial sample in areas of concern. }\end{array}$ \\
\hline \multicolumn{2}{|r|}{ DWIGHT CLAYTON } \\
\hline Measurement wanted: & Status of cable jacket and insulator condition. \\
\hline Current NDE Capability: & Can use TDR and FDR to determine state of conductor. \\
\hline The GAP: & $\begin{array}{l}\text { Harder to determine status of the non-conductor components. Needs to be easy } \\
\text { and simple so NPPs will use. }\end{array}$ \\
\hline \multicolumn{2}{|r|}{ CY SMITH } \\
\hline Measurements wanted: & Remaining useful life at cable. \\
\hline Current NDE Capability: & Find cable, instrument and connector faults. \\
\hline The GAP: & Detect conductor and/or insulation degradation preceding failure and quantity. \\
\hline \multicolumn{2}{|r|}{ KEVIN SIMMONS } \\
\hline Measurement wanted: & $\begin{array}{l}\text { Insulators and jacket material mechanical property measurements that correlate to } \\
\text { aging state. }\end{array}$ \\
\hline Current NDE Capability & $\begin{array}{l}\text { Sound line only one technique currently available. Line Resonance Analysis } \\
\text { (LiRA) }\end{array}$ \\
\hline The GAP: & $\begin{array}{l}\text { Currently not adopted in the US according to Gary Toman. Are there other } \\
\text { methods to do this? Data correlation? Sensitivity? Broad materials Use? What are } \\
\text { the limitations on LiRA? }\end{array}$ \\
\hline \multicolumn{2}{|r|}{ PRADEEP RAMUHALLI } \\
\hline Measurements wanted: & Jack/insulation degradation \\
\hline Current NDE Capability & Indenter/EAB/TDR/FDR/LiRA - remote and local \\
\hline The GAP: & Quantification (i.e. assess detection sensitivity. Acceptance criteria \\
\hline \multicolumn{2}{|r|}{ SHEILA RAY } \\
\hline Measurements wanted: & $\begin{array}{l}\text { Condition monitoring data (electrical, mechanical, dielectric tests) - acceptance } \\
\text { criteria/performance }\end{array}$ \\
\hline Current NDE Capability: & $\begin{array}{l}\text { Acceptance limits available (i.e. elongation@ break to } 50 \% \text { - but this is general } \\
\text { and may not apply to all materials. }\end{array}$ \\
\hline The GAP: & $\begin{array}{l}\text { Data needed to determine when corrective action should be taken. Can use a } \\
\text { representative environment or worst case environment. (hi T, Hi Rad to } \\
\text { combination etc.) }\end{array}$ \\
\hline
\end{tabular}


Table B.2. Brainstorming Gaps Assigned to Group 2

\begin{tabular}{|c|c|}
\hline \multicolumn{2}{|r|}{ Group 2 - CABLE } \\
\hline \multicolumn{2}{|r|}{ HASH HASHEMIAN } \\
\hline Measurements wanted: & R\&D Needs/Gaps \\
\hline Current NDE Capability: & R\&D Needs/Gaps \\
\hline The GAP: & $\begin{array}{l}\text { R\&D Needs: } \\
\text { 1. Determine the type, category and safety classification of sums that are } \\
\text { important to life extension and post- accident service. } \\
\text { 2. Harmonize the regulatory objectives with activities of standard-writing, } \\
\text { community, utilities, R\&D groups and service providers. } \\
\text { 3. Identify what which technique can or cannot do through experimental } \\
\text { laboratory test cables; net paper analysis. }\end{array}$ \\
\hline \multicolumn{2}{|r|}{ CHRISTOPHER LOWE } \\
\hline Measurement wanted: & $\begin{array}{l}\text { Measurement of the amount of thermal/radiation impact on specific location with } \\
\text { electrical based tests. }\end{array}$ \\
\hline Current NDE Capability & $\begin{array}{l}\text { Taking data of thermal/radiation exposed cables. Measurements from electrical } \\
\text { based test (TDR }<\text { IR }<\text { LCR }<\text { FDR) }\end{array}$ \\
\hline The GAP: & $\begin{array}{l}\text { Correlation of the amount of thermal/radiation aging with electrical parameter } \\
\text { results. }\end{array}$ \\
\hline \multicolumn{2}{|r|}{ SHEILA RAY } \\
\hline Measurements wanted: & Service life prediction. \\
\hline Current NDE Capability & Limited models available. \\
\hline The GAP: & Models not available for accurate service life prediction. \\
\hline \multicolumn{2}{|r|}{ GARY TOMAN } \\
\hline Measurements wanted: & All measurements in-situ and laboratory. \\
\hline Current NDE Capability: & Many tests are available to use to assess cable polymer aging. \\
\hline The GAP: & $\begin{array}{l}\text { Plants need the data converted to readily understandable and easily used } \\
\text { acceptance criteria. Plant personnel will not use techniques and data that require } \\
\text { research effort to assess a cable. }\end{array}$ \\
\hline \multicolumn{2}{|r|}{ NICOLA BOWLER } \\
\hline Measurements wanted: & $\begin{array}{l}\text { 1. Polymer weight loss (TCA) as a function of various stressors or long-term } \\
\text { exposure environmental factors, e.g., isothermal heating, voltage, radiation } \\
\text { and others to develop lifetime models. } \\
\text { 2. Electrical properties (macroscopic) of ages insulation polymers (above aging } \\
\text { mechanisms) - include complex sensitivity and breakdown strength. }\end{array}$ \\
\hline Current NDE Capability & $\begin{array}{l}\text { Reflectometry methods for condition faults. LiRA can indicate insulation damage } \\
\text { (?). ISU sensor can infer complex sensitivity from contact capacitore } \\
\text { measurement on insulated wire. }\end{array}$ \\
\hline The GAP: & $\begin{array}{l}\text { Measurement methods for at-a-distance insulation sensitivity/breakdown strength } \\
\text { assessment. }\end{array}$ \\
\hline
\end{tabular}




\begin{tabular}{|l|l|}
\hline \multicolumn{2}{|c|}{ Group 2 - CABLE } \\
\hline \multicolumn{2}{|c|}{ PRADEEP RAMUHALLI } \\
\hline Measurements wanted: & Jacket/insulation degradation state due to thermal/rad aging remotely \\
\hline Current NDE Capability: & $\begin{array}{l}\text { Indenter/EAB, preformed locally. LiRA shows some capability for detecting } \\
\text { insulation degradation remotely. TDR/FDR may be able to also sense some level } \\
\text { of degradation insulation. Unlikely that they can sense jacket degradation. Also } \\
\text { unclear how info can be used to assess "level" of degradation. }\end{array}$ \\
\hline The GAP: & $\begin{array}{l}\text { Remote evaluation of insulation/jacket degradation to assess level of degradation. } \\
\text { Ability to identify jacket degradation from other compounding factors that also } \\
\text { impact remote measurement. }\end{array}$ \\
\hline Measurements wanted: & \multicolumn{1}{c|}{ GARY TOMAN } \\
\hline Current NDE Capability: & $\begin{array}{l}\text { Test of XLPE that may be used in-situ. } \\
\text { used to monitor the thermal aging of XLPE insulation. }\end{array}$ \\
\hline The GAP: & A possibility is to heat the XLPE locally and do a mechanical test. \\
\hline \multicolumn{2}{|l|}{ SASAN BAKHTIARI } \\
\hline Measurements wanted: & $\begin{array}{l}\text { In-situ measurement/monitoring of cable insulation damage degradation. Existing } \\
\text { cable testing methods are all aimed at detecting damage (conductor or insulator) } \\
\text { after the problem arises and not predicting future sate. }\end{array}$ \\
\hline Current NDE Capability: & $\begin{array}{l}\text { Visual testing and thermal imaging techniques seem to be more widely employed } \\
\text { for field applications. }\end{array}$ \\
\hline The GAP: & $\begin{array}{l}\text { Need to develop a robust in-situ/on-line monitoring method for detection of } \\
\text { insulator damage/degradation and predict its remaining useful life. }\end{array}$ \\
\hline
\end{tabular}

Table B.3. Brainstorming Gaps Assigned to Group 3

\begin{tabular}{|l|l|}
\hline \multicolumn{2}{|c|}{ Group 3 - CABLE } \\
\hline \multicolumn{2}{|c|}{ HASH HASHEMIAN } \\
\hline Measurements wanted: & $\begin{array}{l}\text { In-situ techniques for cable condition monitoring (particularly cable insulation } \\
\text { material. }\end{array}$ \\
\hline Current NDE Capability & $\begin{array}{l}\text { Conductor and connector testing capabilities are mature and working. We need } \\
\text { insulation material testing techniques. We also need R\&D people to understand } \\
\text { that plants are interested in simple materials. }\end{array}$ \\
\hline The GAP: & $\begin{array}{l}\text { Need to clearly know what cables are important for cable aging management and } \\
\text { cable condition monitoring. Some people say I\&C cables are predominately the } \\
\text { ones to worry about, and other mediums and high voltage cables are not of } \\
\text { regulatory other concern. }\end{array}$ \\
\hline
\end{tabular}




\begin{tabular}{|c|c|}
\hline \multicolumn{2}{|r|}{ CHAD KIGER } \\
\hline Measurements wanted: & Impact of temperature/radiation on the in-situ or laboratory tests. \\
\hline Current NDE Capability: & $\begin{array}{l}\text { Most tests are laboratory tests performed on samples of cables that have cooled } \\
\text { down and are not in the environment they were under operating conditions. Will } \\
\text { tests performed on cables under operating conditions how different results - is this } \\
\text { a problem? }\end{array}$ \\
\hline The GAP: & $\begin{array}{l}\text { The gap is that there needs to be a way to quantify in-situ the condition of the } \\
\text { cables. Do the cable properties change significantly from laboratory conditions to } \\
\text { the operation environment and is this a concern. Are test results of cold samples } \\
\text { non-conservative. Most plants will be performing these assessments at cold shut } \\
\text { down and not during operation. So even in0situ tests may not be conservative. } \\
\text { What about operating equipment that creates hot spots, if they are not operating } \\
\text { during testing then it may not be an accurate picture. }\end{array}$ \\
\hline \multicolumn{2}{|r|}{ RYAN O'HAGAN } \\
\hline Measurements wanted: & $\begin{array}{l}\text { Independent measurements of the bulk material properties of the cable jacket and } \\
\text { insulation material (e.g., elastic/complex modulus) and how those measurements } \\
\text { correspond to the cables ability to withstand a LOCA event or if it should be } \\
\text { replaced. }\end{array}$ \\
\hline Current NDE Capability: & $\begin{array}{l}\text { Indenter modulus, electrical testing such as } \mathrm{TDR}<\mathrm{FDR}<\mathrm{IR}<\text { etc., visual } \\
\text { inspection, thermography. }\end{array}$ \\
\hline The GAP: & $\begin{array}{l}\text { It is not significantly well understood how current NDE techniques for measuring } \\
\text { the condition of the cable correspond to whether or not it will survive in a design } \\
\text { basis accident or if the cable is still "good" to continue using. }\end{array}$ \\
\hline \multicolumn{2}{|r|}{ CY SMITH } \\
\hline Measurements wanted: & $\begin{array}{l}\text { Verification that cables will survive accident condition (LOCA, etc.) at end of } 40- \\
60 \text { year life. }\end{array}$ \\
\hline Current NDE Capability & Find cable, instrument, and connector faults. \\
\hline The GAP: & Predict cable performance under accident conditions. \\
\hline \multicolumn{2}{|r|}{ STEVE JOHNSON } \\
\hline Measurements wanted: & $\begin{array}{l}\text { When cables are installed they are often pulled into place much like an un- } \\
\text { intentional EAR. Is there a way to identify, in-situ, whether a cable has already } \\
\text { been mechanically 'stressed'? }\end{array}$ \\
\hline Current NDE Capability: & Many rests identify faults (or work together to identify faults). \\
\hline The GAP: & $\begin{array}{l}\text { Is there a set of tests that would identify a 'weaker' cable that has not yet } \\
\text { developed a fault? Is a weakened cable more likely to develop a fault in the } \\
\text { 'weak' area? Do the electrical properties change through mechanical stressing } \\
\text { and, if so, how? }\end{array}$ \\
\hline \multicolumn{2}{|r|}{ CRAIG HARRIS } \\
\hline Measurements wanted: & NDE data to correlate to indenter modulus with more specific acceptable criteria. \\
\hline Current NDE Capability: & Indenter modulus. \\
\hline The GAP: & $\begin{array}{l}\text { The indenter modulus strongly correlates to destructive, mechanical test such as } \\
\text { EAB (which does not have a clear defined acceptable criteria due to it is a very } \\
\text { polymer specific test). Strong NDE tests are needed for correlation with more } \\
\text { specific acceptable criteria. }\end{array}$ \\
\hline
\end{tabular}




\begin{tabular}{|c|c|}
\hline \multicolumn{2}{|r|}{ TIM RONEY } \\
\hline Measurements wanted: & Pre-failure condition(s) of cabling including insulation. \\
\hline Current NDE Capability: & $\begin{array}{l}\text { Several independent measurements have been researched, some have been } \\
\text { deployed. }\end{array}$ \\
\hline The GAP: & $\begin{array}{l}\text { Ability to derive higher probability of determining condition from complementary } \\
\text { measurements. Ability to utilize existing information to predict remaining useful } \\
\text { life, or, time to failure. }\end{array}$ \\
\hline \multicolumn{2}{|r|}{ DARA CUMMINS } \\
\hline Measurements wanted: & She didn't write anything here. \\
\hline Current NDE Capability & IR, LCR, FDR, TDR, Tan Delta, On-line Partial Discharge, Indenter, RTDR \\
\hline The GAP: & $\begin{array}{l}\text { 1. Actual plant data. } \\
\text { 2. More lab data available to entire industry related to aging. } \\
\text { 3. More specifics about what regulatory drivers will be required in the future. } \\
\text { 4. New and innovative passive tests that can be done at power and on-line that } \\
\text { correlate to aging and RUL (remaining useful life). } \\
\text { 5. What tests give you tenable data? }\end{array}$ \\
\hline
\end{tabular}

\section{B.2 Develop Proposed NDE R\&D Activities}

Working groups were instructed to develop proposals that address specific gaps. They identified the research objectives, scope, schedule, budget, and outcomes for each proposed R\&D effort. They also indicated the relative priority of each NDE R\&D proposal.

\section{B.2.1 Working Group Assignments}

Following a brainstorming activity three working groups were formed. Each group was given the assignment to develop R\&D proposals to address the gaps in cable qualification, aging management, and condition monitoring methods. Table B.4 shows the three groups. 
Table B.4. Work Group Members

\begin{tabular}{|c|c|c|}
\hline Group 1 & Group 2 & Group 3 \\
\hline - $\quad$ Kevin Simmons (Lead) & - Leonard Bond (Lead) & - $\quad$ Pradeep Ramuhalli (Lead) \\
\hline $\begin{array}{l}\text { - John Lindberg } \\
\text { EPRI }\end{array}$ & $\begin{array}{ll}\text { - } & \text { Robert Konnik } \\
\text { Rockbestos Cable }\end{array}$ & $\begin{array}{l}\text { - Jamie Coble } \\
\text { PNNL }\end{array}$ \\
\hline $\begin{array}{l}\text { - Aladar Csontos } \\
\text { NRC }\end{array}$ & $\begin{array}{l}\text { - } \quad \text { Sasan Bakhtiari } \\
\text { ANL }\end{array}$ & $\begin{array}{l}\text { - } \quad \text { Tim Roney } \\
\text { INL }\end{array}$ \\
\hline $\begin{array}{ll}- & \text { Vnu Varma } \\
& \text { ORNL }\end{array}$ & $\begin{array}{l}\text { - Dwight Clayton } \\
\text { ORNL }\end{array}$ & $\begin{array}{ll}- & \text { Cy Smith } \\
\text { ORNL }\end{array}$ \\
\hline $\begin{array}{ll}- & \text { Nicola Bowler } \\
& \text { Iowa State University }\end{array}$ & $\begin{array}{l}-\quad \text { Sheila Ray } \\
\text { NRC }\end{array}$ & $\begin{array}{l}-\quad \text { Gary Toman } \\
\text { EPRI }\end{array}$ \\
\hline $\begin{array}{ll}\text { - John Lareau } & \text { JesDyne }\end{array}$ & $\begin{array}{ll}- & \text { Thomas Rosseel } \\
& \text { ORNL }\end{array}$ & $\begin{array}{ll}- & \text { John Popovics } \\
& \text { University of Illinois }\end{array}$ \\
\hline $\begin{array}{c}-\quad \text { Hash Hashemian } \\
\text { AMS Corporation }\end{array}$ & $\begin{array}{ll}- & \text { Casey Sexton } \\
& \text { AMS Corporation }\end{array}$ & $\begin{array}{l}-\quad \text { Ryan O'Hagan } \\
\text { AMS Corporation }\end{array}$ \\
\hline $\begin{array}{l}-\quad \text { Dara Cummins } \\
\text { AMS Corporation }\end{array}$ & $\begin{array}{l}-\quad \text { Josh Cole } \\
\text { AMS Corporation }\end{array}$ & $\begin{array}{ll}-\quad \text { Bryan McConkey } \\
\text { AMS Corporation }\end{array}$ \\
\hline $\begin{array}{l}\text { Jonathan Ledlow } \\
\text { AMS Corporation }\end{array}$ & $\begin{array}{l}\text { - Chris Lowe } \\
\text { AMS Corporation }\end{array}$ & $\begin{array}{ll}- & \text { Chad Kiger } \\
& \text { AMS Corporation } \\
-\quad & \text { Craig Harris } \\
& \text { AMS Corporation }\end{array}$ \\
\hline
\end{tabular}

\section{B.2.2 Working Group Instructions}

The working groups discussed the GAPS and then set about creating NDE R\&D proposals to address the GAPS. For each proposal the group addressed the following elements:

- Measurement wanted:

- Current NDE Capability:

- The GAP:

- Research Objective:

- Scope of Work:

- Expected Outcomes:

- Schedule:

- Budget:

- Ranking:

The group ranked the relative priority of each NDE R\&D proposal (high, medium or low) according to three criteria: 
1. Relative importance in "filling a NDE Technology and methodology gap." Solving a big problem for MADD or a tiny one?

2. Achievability within the constraints of 3-4 years to do a field demonstration.

3. Acceptability - likelihood that stakeholders will support its use. Is it mature enough to be accepted and put to use?

\section{B.2.3 Working Group Reports}

The results from the three working groups follow:

\section{Group 1 (Leader: Kevin Simmons)}

\begin{tabular}{|c|c|}
\hline \multicolumn{2}{|r|}{ Topic 1. Identify Key Indicators of Cable Degradation } \\
\hline Measurements wanted: & Electrical and physical measurements which correlate with cable degradation. \\
\hline Current NDE Capability: & Several or none? \\
\hline The GAP: & $\begin{array}{l}\text { Knowledge of key physical parameters that indicate cable insulation degradation } \\
\text { state. }\end{array}$ \\
\hline Research Objective: & Identify key indicator(s) for cable degradation. \\
\hline Scope of Work: & $\begin{array}{l}\text { Develop experimentally-validated physical models of electrical, mechanical, and } \\
\text { other polymer insulation properties to establish sensitivity to degradation, } \\
\text { informing the selection and/or development of successful NDE techniques. } \\
\text { a. Establish a physical model that describes the polymer behavior. } \\
\text { b. Validate the model with standard laboratory experiments. } \\
\text { c. Use FDR, FTIR, Modulus, Elongation, Dielectric Constant and Loss } \\
\text { Tangent for experimental correlation. }\end{array}$ \\
\hline Expected Outcomes: & $\begin{array}{l}\text { Determination of most sensitive test for insulation health assessment, constrained } \\
\text { by cost-effectiveness and ease of application in the field. }\end{array}$ \\
\hline Schedule: & 3 years \\
\hline Budget: & $\$ 500,000$ to $\$ 3 \mathrm{M}$ \\
\hline Ranking: & High (underpins technology development) \\
\hline \multicolumn{2}{|c|}{ Topic 2. Integration of Polymer Science and Measurement Technology } \\
\hline Measurements wanted: & $\begin{array}{l}\text { Electrical measurements and physical properties that correlate to cable } \\
\text { degradation. }\end{array}$ \\
\hline Current NDE Capability: & FDR/TDR, indenter modulus/relaxation. \\
\hline The GAP: & Absence of polymer expertise in cable testing. \\
\hline Research Objective: & Integration of polymer science and measurement technology. \\
\hline Scope of Work: & $\begin{array}{l}\text { Mix polymer science with measurement knowledge to arrive at a practical means } \\
\text { to identify and locate problems in insulation material along the installed cable. }\end{array}$ \\
\hline Expected Outcomes: & Ability to perform in-situ cable condition monitoring program. \\
\hline Schedule: & 3 years \\
\hline Budget: & $\$ 1.5 \mathrm{M}$ \\
\hline Ranking: & 2 \\
\hline
\end{tabular}


Topic 3. Development of Wave Guided (Ultrasonic) Signal for Insulation Material Testing

\begin{tabular}{|l|l|}
\hline Measurements wanted: & Not provided \\
\hline Current NDE Capability: & Not provided \\
\hline The GAP: & Not provided \\
\hline Research Objective: & Wave guided ultrasonic signal for insulation material testing. \\
\hline Scope of Work: & $\begin{array}{l}\text { Investigate ultrasonic technology for wave guiding frequencies through insulators } \\
\text { for predicting cable aging conditions and faults. }\end{array}$ \\
\hline Expected Outcomes: & Development of new NDE technology for non-contact measurement. \\
\hline Schedule: & 3 years \\
\hline Budget: & $\$ 1.5 \mathrm{M}$ \\
\hline Ranking: & 3 \\
\hline
\end{tabular}

\section{Group 2 (Leader: Leonard Bond)}

\section{Topic 1. Modeling to Predict Realistic Aging Effects}

\begin{tabular}{|c|c|}
\hline \multicolumn{2}{|r|}{ Topic 1. Modeling to Predict Realistic Aging Effects } \\
\hline Measurements wanted: & $\begin{array}{l}\text { Service Life Prediction (cable aging prognostic) to help validate differences in } \\
\text { natural vs. artificial aging. }\end{array}$ \\
\hline Current NDE Capability: & $\begin{array}{l}\text { We lack local temperature and other environmental data } \\
\text { - Model validation, accelerated aging, shelf vs. service life. } \\
\text { - Measured cables not as degraded as expected, designed for 90C - assume 40C, } \\
\text { are the models too conservative? }\end{array}$ \\
\hline The GAP: & $\begin{array}{l}\text { Better model to predict realistic aging effects - need to validate - ability to predict } \\
\text { remaining service life. }\end{array}$ \\
\hline Research Objective: & $\begin{array}{l}\text { Develop better model to predict realistic aging effects, and to validate model and } \\
\text { be able to predict remaining service life. }\end{array}$ \\
\hline Scope of Work: & $\begin{array}{l}\text { (i) gather existing naturally aged cable \& data, (ii) develop a model, (iii) validate } \\
\text { model through both natural and accelerated aging both natural and accelerated } \\
\text { aged, iv) demonstrate prognostic. }\end{array}$ \\
\hline Expected Outcomes: & Ability to predict remaining cable service life. \\
\hline Schedule: & 4 years \\
\hline Budget: & 2 FTE at 4 years, $\$ 500 \mathrm{k}$ per year (DOE Lab), $\$ 100 \mathrm{k}$ : $\$ 2.1 \mathrm{M}$ total \\
\hline Ranking: & High \\
\hline \multicolumn{2}{|c|}{ Topic 2. In-situ/On-line Measurements of Insulation Degradation } \\
\hline Measurements wanted: & Insulation Degradation - In-service. \\
\hline Current NDE Capability: & Current visual and thermal. \\
\hline The GAP: & $\begin{array}{l}\text { Need in-situ or on-line measurements of insulation degradation. Measurements } \\
\text { needed along length of cable (not just a local measurement). Be able to use data } \\
\text { (in models from topic \#1) to predict life. }\end{array}$ \\
\hline Research Objective: & $\begin{array}{l}\text { Provide in situ or on-line measurements of insulation degradation along length of } \\
\text { cable (not just a local measurement). Be able to use data (in models from project } \\
\# 1 \text { ) to predict life. }\end{array}$ \\
\hline
\end{tabular}




\begin{tabular}{|c|c|}
\hline Scope of Work: & $\begin{array}{l}\text { Review limits of reflectometry (conductor focused). Insulation characterization - } \\
\text { from cable end - Do expanded impedance measurements or line resonance } \\
\text { analysis - [FDR (with spin)] make sense? }\end{array}$ \\
\hline Expected Outcomes: & Novel on-line measurements. \\
\hline Schedule: & $4+$ years (may be several phases) - could be more than one project. \\
\hline Budget: & $\begin{array}{l}4 \text { FTE, } \$ 1 \mathrm{M} \text { per year, equipment TBD: } \$ 4 \mathrm{M}+\text { total } \\
\text { - Perhaps a one year Phase I could be funded to determine feasibility } \\
\text { - Several NEUP, SBIR, or Lab projects (then down select) }\end{array}$ \\
\hline Ranking: & High \\
\hline \multicolumn{2}{|r|}{ Topic 3. Tool to Provide Local Test for Condition of XLPE } \\
\hline Measurements wanted: & $\begin{array}{l}\text { Test of XLPE in-situ - crystallinity masks thermal aging when } \\
\text { measured with indenter. }\end{array}$ \\
\hline Current NDE Capability: & Indenter technology which does not give good data. \\
\hline The GAP: & A tool to provide a local test for condition of XLPE. \\
\hline Research Objective: & A tool to provide a local test for condition of XLPE. \\
\hline Scope of Work: & $\begin{array}{l}\text { Generate a good idea! Test option of heating to remove crystallinity, which } \\
\text { masks thermal aging when measured with indenter. Validate new } \\
\text { measurement/heating approach. }\end{array}$ \\
\hline Expected Outcomes: & New local anneal and measurement approach. \\
\hline Schedule: & 2 years \\
\hline Budget: & 1 FTE, \$250k per year, equipment \$150k: \$650k total \\
\hline Ranking: & $\begin{array}{l}\text { High: Cable type used for } 50 \% \text { of safety related cables - low hanging fruit [if it } \\
\text { works]. Could leverage Canadian work. }\end{array}$ \\
\hline \multicolumn{2}{|c|}{ Topic 4. Remote Evaluation that Discriminates Between Jacket and Other Cable Elements } \\
\hline Measurements wanted: & $\begin{array}{l}\text { In-situ jacket and insulation condition assessment for aging effects due to } \\
\text { radiation and thermal phenomena. }\end{array}$ \\
\hline Current NDE Capability: & Various reflectometry, line resonance analysis, indenter. \\
\hline The GAP: & $\begin{array}{l}\text { Hard to quantify degree of degradation from available data. Remote evaluation } \\
\text { needed - that discriminate between jacket and other cable elements. }\end{array}$ \\
\hline Research Objective: & $\begin{array}{l}\text { Provide remote evaluation that discriminates between jacket and other cable } \\
\text { elements. Provide a tool that can quantify degree of degradation. }\end{array}$ \\
\hline Scope of Work: & $\begin{array}{l}\text { Develop sample set. Laboratory testing. Demonstrate a new measurement } \\
\text { approach. }\end{array}$ \\
\hline Expected Outcomes: & New measurement approach \\
\hline Schedule: & 3 years \\
\hline Budget: & 2 FTE, $\$ 500 \mathrm{k}$ per year, equipment $\$ 200 \mathrm{k}: \$ 1.7 \mathrm{M}$ total \\
\hline Ranking: & Medium to High \\
\hline \multicolumn{2}{|r|}{ Topic 5. Measurement Methods for In-situ Operation } \\
\hline Measurements wanted: & $\begin{array}{l}\text { Polymer weight loss as function of environment and electrical measurement of } \\
\text { permittivity and breakdown strength. }\end{array}$ \\
\hline Current NDE Capability: & $\begin{array}{l}\text { Reflectometry, density (destructive or acoustic), line resonance analysis -- small } \\
\text { changes - natural sample variability add scatter in data. Selected sensors can } \\
\text { potentially infer complex permittivity from contact capacitance. }\end{array}$ \\
\hline The GAP: & Measurement methods for in-situ operation. \\
\hline
\end{tabular}




\begin{tabular}{|c|c|}
\hline Research Objective: & Provide measurement methods for in-situ operation. \\
\hline Scope of Work: & $\begin{array}{l}\text { Prepare calibrated samples. Develop and demonstrate sensors that can infer } \\
\text { complex permittivity from contact capacitance. }\end{array}$ \\
\hline Expected Outcomes: & New measurement technique. \\
\hline Schedule: & 3 years \\
\hline Budget: & 1 FTE, $\$ 250 \mathrm{k}$ per year, equipment $\$ 75 \mathrm{k}: \$ 825 \mathrm{k}$ total \\
\hline Ranking: & Low to Medium \\
\hline \multicolumn{2}{|c|}{ Topic 6. Correlate Thermal Radiation Aging with Electrical Parameter Results } \\
\hline Measurements wanted: & Approach to correlate thermal radiation aging with electrical parameter results. \\
\hline Current NDE Capability: & All electrical tests as specified in regulatory guide 1.218 . \\
\hline The GAP: & The ability to correlate thermal radiation aging with electrical parameter results. \\
\hline Research Objective: & $\begin{array}{l}\text { To provide the ability to correlate thermal radiation aging with electrical } \\
\text { parameter results. }\end{array}$ \\
\hline Scope of Work: & $\begin{array}{l}\text { - Calibrated samples using exposure test rig. } \\
\text { - Perform electrical measurements (various). } \\
\text { - Demonstrate correlation - aging and electrical parameters. }\end{array}$ \\
\hline Expected Outcomes: & New measurement technique and insights needed to develop guidance. \\
\hline Schedule: & 3 years \\
\hline Budget: & 1 FTE, $\$ 250 \mathrm{k}$ per year, equipment $\$ 250 \mathrm{k}: \$ 1 \mathrm{M}$ total \\
\hline Ranking: & Medium \\
\hline \multicolumn{2}{|c|}{ Topic 7. Readily Understandable and Easily Used Acceptance Criteria } \\
\hline Measurements wanted: & Acceptance criteria for the various measurement methods. \\
\hline Current NDE Capability: & $\begin{array}{l}\text { There are many methods we need to convert data into readily understandable and } \\
\text { easily used acceptance criteria. }\end{array}$ \\
\hline The GAP: & Readily understandable and easily used acceptance criteria. \\
\hline Research Objective: & Provide readily understandable and easily used acceptance criteria. \\
\hline Scope of Work: & $\begin{array}{l}\text { Gather available data. Understand sensitivity to degradation. Develop and test } \\
\text { acceptance criteria. }\end{array}$ \\
\hline Expected Outcomes: & Basis for new acceptance criteria \\
\hline Schedule: & 2 years \\
\hline Budget: & 1 FTE, $\$ 250 \mathrm{k}$ per year: $\$ 500 \mathrm{k}$ total \\
\hline Ranking: & High \\
\hline
\end{tabular}

\section{Group 3 (Leader: Pradeep Ramuhalli)}

\section{Topic 1. Predict Cable Performance Under Accident Conditions Using Condition-Based Methods}

\begin{tabular}{|l|l|} 
Measurements wanted: & $\begin{array}{l}\text { Verification that cables will survive accident conditions using condition-based } \\
\text { methods. }\end{array}$ \\
\hline Current NDE Capability: & $\begin{array}{l}\text { Methods which primarily find cable, connector, and instrument faults. } \\
\text { Predict cable performance and remaining useful life under accident conditions } \\
\text { using condition based methods. } \\
\text { Example: Correlate destructive (EAB) with NDE data. }\end{array}$ \\
\hline Research Objective: & Correlate NDE measurements with end of life criteria whether LOCA or \\
\hline
\end{tabular}




\begin{tabular}{|c|c|}
\hline & operational end-of-life. \\
\hline Scope of Work: & $\begin{array}{l}\text { - Accelerated aging tests coupled with condition assessment (measurements) to } \\
\text { generate data set. } \\
\text { - Use data from existing databases - correlate with end of life criteria. }\end{array}$ \\
\hline $\begin{array}{l}\text { Expected Outcomes: } \\
\text { Schedule: }\end{array}$ & $\begin{array}{l}\text { - Acceptance criteria, models of aging and degradation. } \\
\text { - Ranking of NDE measurements with respect to sensitivity, repeatability, } \\
\text { consistency of procedures to conduct the test. } \\
3-4 \text { years }\end{array}$ \\
\hline Budget: & Not provided \\
\hline Ranking: & High \\
\hline \multicolumn{2}{|c|}{ Topic 2. Use Currently Available Measurement Technologies for RUL Estimation } \\
\hline Measurements wanted: & NDE measurements which can be used to predict remaining useful life of cables. \\
\hline Current NDE Capability: & Electrical, mechanical, and chemical testing. \\
\hline The GAP: & Utilize information from one or more measurements to predict remaining life. \\
\hline Research Objective: & Use currently available measurement technologies for RUL estimation. \\
\hline Scope of Work: & $\begin{array}{l}\text { - Define available information (aging tests, legacy information from topic \# 1, } \\
\text { measurement data on cables) } \\
\text { - Develop models of aging and degradation } \\
\text { - Develop condition-based prognostics }\end{array}$ \\
\hline Expected Outcomes: & $\begin{array}{l}\text { - Models } \\
\text { - Methodology for RUL estimation } \\
\text { - Procedures for implementation } \\
\end{array}$ \\
\hline Schedule: & Not provided \\
\hline Budget: & Not provided \\
\hline Ranking: & Not provided \\
\hline \multicolumn{2}{|c|}{ Topic 3. Development/Evaluation of Innovative In-situ Tests for Cable Aging and RUL } \\
\hline Measurements wanted: & In-situ, NDE tests which correlate highly with cable degradation and age. \\
\hline Current NDE Capability: & Electrical, mechanical, and chemical testing. \\
\hline The GAP: & $\begin{array}{l}\text { Innovative in-situ nondestructive tests which correlate with aging and remaining } \\
\text { life. }\end{array}$ \\
\hline Research Objective: & Develop and evaluate innovative in-situ tests \\
\hline Scope of Work: & $\begin{array}{l}\text { - New NDE methods for in-situ cable condition evaluation } \\
\text { - Chemical sensing? Other methods? } \\
\text { - Evaluate new methods for repeatability of procedures and continuity of } \\
\text { equipment. } \\
\text { - Further develop and evaluate existing methods as well for sensitivity, } \\
\text { repeatability. }\end{array}$ \\
\hline Expected Outcomes: & $\begin{array}{l}\text { - Develop new NDE methods for cable condition monitoring } \\
\text { - Advancement of current NDE methods }\end{array}$ \\
\hline Schedule: & Not provided \\
\hline Budget: & Not provided \\
\hline Ranking: & Not provided \\
\hline
\end{tabular}




\section{B.3 Prioritize Cable NDE R\&D}

To evaluate and rank the proposals for NDE R\&D each participant was give six (6) total votes. $\mathrm{He} / \mathrm{she}$ could cast no more than three votes for any one proposal. The following table shows the summary of votes cast. It was realized that some of the proposals developed by the three workings groups were ve4ry similar. For example, Proposal \#1 by Group 2 and Proposal \#1 by Group 3. Also Proposal \#2 by Group 2 and Proposal \#3 by Group \#3.

The voting and the discussion that followed were used to identify higher priority NDE R\&D activities.

The results from the workshop generated three key areas of importance:

1. Determining key indicators of cable aging that correlate with measureable changes in material properties at macroscopic scale

2. Advance state-of-the-art in current cable NDE methods and develop new and transformational NDE methods. The data for these developments would be from samples generated from laboratory cable aging experiments and field samples.

3. Develop models for predicting remaining useful life of cables based on condition indices. The data for these models would come from existing databases, the information generated in topic 1 and 2, and other possible sources.

\begin{tabular}{|c|l|c|}
\hline \multicolumn{1}{|c|}{ Proposal Description } & Results of Vote \\
\hline \multicolumn{2}{|c|}{ Group 1 } & 29 \\
\hline 1. & Identify Key Indicators of Cable Degradation & 11 \\
\hline 2. & Integration of Polymer Science and Measurement Technology & 7 \\
\hline 3. & Development of Wave Guided (Ultrasonic) Signal for Insulation Material Testing & 19 \\
\hline \multicolumn{2}{|c|}{ Group 2 } & 17 \\
\hline 1. & Modeling to Predict Realistic Aging Effects & 6 \\
\hline 2. & In-Situ/On-line Measurements of Insulation Degradation & 1 \\
\hline 3. & Tool to Provide Local Test for Condition of XLPE & 0 \\
\hline 4. & Remote Evaluation that Discriminates Between Jacket and Other Cable Elements & 1 \\
\hline 5. & Measurement Methods for In-Situ Operation & 14 \\
\hline 6. & Correlate Thermal Radiation Aging with Electrical Parameter Results \\
\hline 7. & Readily Understandable and Easily Used Acceptance Criteria & 19 \\
\hline & \multicolumn{1}{|c|}{ Group 3 } & 6 \\
\hline 1. & \begin{tabular}{l} 
Predict Cable Performance Under Accident Conditions Using Condition-Based \\
\hline 2.
\end{tabular} & Use Currently Available Measurement Technologies for RUL Estimation \\
\hline 3. & Development/Evaluation of Innovative In-Situ Tests for Cable Aging and RUL & 24 \\
\hline
\end{tabular}

In discussions the the overwhelming majority of the responses asked for "a correlation between cable conditions/age and measureable electrical, mechanical, or chemical properties of a cable". 
A discussion on regulatory requirements ensued for setting the stage for how important it is for regulators and operators to have the ability for diagnosing the aged conditions of the cables for life determination for relicensing and safety. For license renewal, NUREG-1801, "Generic Aging Lessons Learned (GALL) Report," recommends a condition monitoring program in Chap. XI.E3, "Inaccessible Power Cables Not Subject to 10 CFR 50.49." Chapter XI.E2, "Insulation Material for Electrical Cables and Connections Not Subject to 10 CFR 50.49 Environmental Qualification Requirements Used in Instrumentation Circuits," documents two methods that can be used to identify the existence of aging degradation. In the first method, calibration results or findings of surveillance testing programs are evaluated to identify the existence of cable and connection insulation material aging degradation. In the second method, direct testing of the cable system is performed. In addition, Chapter X1.E1, "Insulation Material for Electrical Cables and Connections Not Subject To 10 CFR 50.49 Environmental Qualification Requirements," recommends a condition monitoring program for accessible electrical cables and connections within the scope of license renewal that are located in adverse localized environments caused by temperature, radiation, or moisture. NUREG/CR-6704 addresses issues related to the qualification process for low-voltage I\&C cables used in commercial NPPs. 


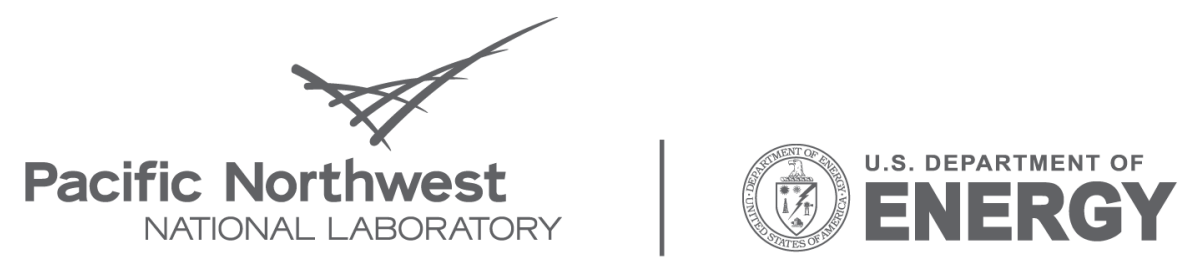

Proudly Operated by Battelle Since 1965

902 Battelle Boulevard

P.O. Box 999

Richland, WA 99352

1-888-375-PNNL (7665)

www.pnl.gov 